\title{
Nucleus Accumbens Drd1-Expressing Neurons Control Aggression Self-Administration and Aggression Seeking in Mice
}

\author{
@Sam A. Golden, @Michelle Jin, Conor Heins, Marco Venniro, @Michael Michaelides, and $\odot$ Yavin Shaham \\ Intramural Research Program, National Institute on Drug Abuse-National Institutes of Health, Baltimore, Maryland 21224
}

We recently developed a mouse model of appetitive operant aggression and reported that adult male outbred CD-1 mice lever-press for the opportunity to attack subordinate male mice and relapse to aggression seeking during abstinence. Here we studied the role of nucleus accumbens (NAc) dopamine receptor (Drd)1- and Drd2-expressing neurons in aggression self-administration and aggression seeking. We trained CD-1 mice to self-administer intruders $(9 \mathrm{~d}, 12$ trials/d) and tested them for aggression self-administration and aggression seeking on abstinence Day 1 . We used immunohistochemistry and in situ hybridization to measure the neuronal activity marker Fos in the NAc, and cell-type-specific colocalization of Fos with Drd1- and Drd2-expressing neurons. To test the causal role of Drd1- and Drd2-expressing neurons, we validated a transgenic hybrid breeding strategy crossing inbred Drd1-Cre and Drd2-Cre transgenic mice with outbred CD-1 mice and used cell-type-specific Cre-DREADD (hM4Di) to inhibit NAc Drd1- and Drd2-expressing neuron activity. We found that aggression self-administration and aggression seeking induced higher Fos expression in NAc shell than in core, that Fos colocalized with Drd1 and Drd2 in both subregions, and that chemogenetic inhibition of Drd1-, but not Drd2-, expressing neurons decreased aggression self-administration and aggression seeking. Results indicate a cell-type-specific role of Drd1-expressing neurons that is critical for both aggression self-administration and aggression seeking. Our study also validates a simple breeding strategy between outbred CD-1 mice and inbred C57-based Cre lines that can be used to study cell-type and circuit mechanisms of aggression reward and relapse.

Key words: accumbens; addiction; aggression; motivation; relapse; reward

Significance Statement

Aggression is often comorbid with neuropsychiatric diseases, including drug addiction. One form, appetitive aggression, exhibits symptomatology that mimics that of drug addiction and is hypothesized to be due to dysregulation of addiction-related reward circuits. However, our mechanistic understanding of the circuitry modulating appetitive operant aggression is limited. Here we used a novel mouse model of aggression self-administration and relapse, in combination with immunohistochemistry, in situ hybridization, and chemogenetic manipulations to examine how cell types in the nucleus accumbens are recruited for, and control, operant aggression self-administration and aggression seeking on abstinence Day 1 . We found that one population, dopamine receptor 1-expressing neurons, act as a critical modulator of operant aggression reward and aggression seeking.

\section{Introduction}

In humans, aggression is a complex adaptive behavior that spans a continuum from reactive and instrumental to appetitive or re-

Received Sept. 18, 2018; revised Dec. 21, 2018; accepted Jan. 7, 2019.

Author contributions: S.A.G. wrote the first draft of the paper; S.A.G., M.J., C.H., M.V., M.M., and Y.S. edited the paper; S.A.G., M.J., C.H., M.V., and Y.S. designed research; S.A.G., M.J., C.H., and M.V. performed research; M.M. contributed unpublished reagents/analytic tools; S.A.G., M.J., C.H., M.V., and Y.S. analyzed data; S.A.G., M.J., and Y.S. wrote the paper.

This work was supported by the Intramural Research Program of the National Institute on Drug Abuse (NIDA; to Y.S.) and PRAT 1FI2GM117583-01 and NIDA K99 DA045662-01 (S.A.G.). We thank Joseph Nguyen for assisting in running the experiments.

The authors declare no competing financial interests. warding aggression (Moran et al., 2014; de Almeida et al., 2015; Chester and DeWall, 2016). Each variation is associated with its own behavioral characteristics, functionality, and neural basis that may transition from adaptive to maladaptive, depending on genetic and environmental factors (Lacourse et al., 2002; Proven-

Correspondence should be addressed to Sam A. Golden at sagolden@uw.edu or Yavin Shaham at yshaham@intra.nida.nih.gov.

C. Heins' present address: International Max Planck Research School, University of Göttingen, Göttingen 37077, Germany.

S. A. Golden's present address: University of Washington, Department of Biological Structure, Seattle, WA 98195 https://doi.org/10.1523/JNEUROSCI.2409-18.2019

Copyright $\odot 2019$ the authors $\quad 0270-6474 / 19 / 392482-15 \$ 15.00 / 0$ 
çal et al., 2015). At the extreme, pathological aggression mimics cardinal features of drug addiction like being highly rewarding and robustly pursued despite immediate or long-term adverse consequences (Porges and Decety, 2013; Chester et al., 2016). Additionally, relapse (recidivism) rates of aggressive violent offenders are as high as relapse rates observed in drug addicts (Hunt et al., 1971; Sinha, 2011; Durose et al., 2014). It is hypothesized that pathological aggression is a consequence of excessive activation of evolutionarily conserved reward circuits, in a manner like drug addiction (Golden and Shaham, 2018). However, our mechanistic understanding of the reward-related brain regions and circuits guiding operant aggression-seeking behaviors is limited.

In preclinical studies, investigators have used procedures initially developed to examine natural and drug reward, selfadministration (Fish et al., 2005; Couppis and Kennedy, 2008; Falkner et al., 2016; Golden et al., 2017a) and conditioned place preference (CPP; Golden et al., 2016, 2017b; Aleyasin et al., 2018 b), to demonstrate that aggression can be highly rewarding in older male mice. More recently, we introduced a high throughput and standardized operant aggression procedure where aggressive mice exhibit robust relapse to aggression seeking (operationally defined as persistent lever-pressing under extinction conditions) after prolonged abstinence or suppression of aggression seeking, whether the abstinence is forced, punished, or choice-based (Golden et al., 2017a). Here we used this procedure to study the underlying mechanisms of aggression self-administration and aggression seeking during early abstinence.

We focused on the nucleus accumbens (NAc), which earlier research has implicated in aggression self-administration and CPP (Couppis and Kennedy, 2008; Golden et al., 2016; Aleyasin et al., 2018b). There has been a recent interest in the role of the mesolimbic dopaminergic circuit in controlling aggression reward (Flanigan et al., 2017; Aleyasin et al., 2018a; Yamaguchi and Lin, 2018), as dopaminergic projections from the ventral tegmental area (VTA) to the NAc modulate both aggression intensity (Yu et al., 2014) and NAc dopamine levels (van Erp and Miczek, 2000, 2007). Additionally, local dopamine receptor blockade decreases aggression-reinforced operant responding (Couppis and Kennedy, 2008).

The NAc's major projection neurons are GABAergic dopamine receptor (Drd)1- and Drd2-expressing neurons, which predominantly (Gerfen et al., 1990; Gerfen, 1992), but not exclusively (Kupchik et al., 2015), project along the direct (Drd1) or indirect (Drd2) pathways. These populations have unique neurochemical signatures (Gerfen et al., 1990) and afferent and efferent connectivity (Gerfen, 1992; Kupchik et al., 2015). Recent studies showed that cocaine reward and relapse/reinstatement (Lobo et al., 2010; Grueter et al., 2013; Heinsbroek et al., 2017) and social stress (Francis et al., 2015; Fox et al., 2018) are controlled by different Drd1- and Drd2-expressing cell types in NAc. Most recently, within the context of aggression CPP, a study by Aleyasin et al. (2018b) explored the cell-type-specific role of the addiction-associated transcription factor $\Delta$ FosB in NAc, demonstrating that $\Delta$ FosB expression in Drd1-expressing neurons promotes aggressive behavior.

However, limited data are available on the role of NAc cell types in operant aggression self-administration and aggression seeking during abstinence. Here we use immunohistochemistry, in situ hybridization (ISH), and chemogenetic manipulations to examine how cell types in the NAc are recruited for, and modulate, operant aggression self-administration and aggression seeking. We found that one population, Drd1-expressing neurons, acts as a critical modulator of both operant aggression selfadministration and aggression seeking during early abstinence.

\section{Materials and Methods}

\section{Subjects}

For resident mice, we used $\sim 40 \mathrm{~g} 3$ - to 6-month-old sexuallyexperienced male CD-1 $[n=54$; Charles River Laboratories (CRL); IMSR catalog \#Crl:CD1(ICR); RRID:IMSR_CRL:22]. For hybrid resident mice, we used $\sim 40 \mathrm{~g} 3$ - to 6-month-old sexually-naive male CD-1 $\times$ D1-Cre hybrid mice $(n=79)$ and CD-1 $\times$ D2-Cre hybrid mice $(n=91)$ that were positively genotyped for Cre recombinase and bred in-house at our institute. For Experiment 3, we also used Cre-negative CD-1 $\times$ D1Cre hybrid mice $(n=14)$ and CD- $1 \times$ D2-Cre hybrid mice $(n=21)$. We confirmed with CRL animal facility staff that the sexually-experienced CD-1 mice had equal access to receptive females. Specifically, CRL begins pair-housing male CD-1 mice with several females (harem breeding) at P28, and then continually keep male CD-1 mice group-housed with the receptive females until they are purchased. Pregnant females are switched with new non-pregnant females, with no break between cycles. Male CD-1 mice that do not successfully breed are removed from the breeding pool and are not made available for purchase. We bred the F1-hybrid mice by crossing a D1- (MGI ID: 3836633) or D2- (MGI ID: 3836635) Cre male (on C57BL/6J background) with two CD-1 females (harem breeding). We genotyped the F1 offspring (Transnetyx) and weaned them 3-4 weeks after birth. We used this hybrid breeding strategy to allow cell-type-specific manipulations in innately aggressive mice. We validated hybrid mice for resident-intruder aggression, aggression selfadministration, aggression seeking, developmental characteristics, and DREADD expression.

For intruders, we used male 8- to 12-week-old sexually-naive subordinate C57BL/6J (C57) mice (Jackson Laboratories; IMSR catalog\#JAX: 000664; RRID:IMSR_JAX:000664), primarily because of their well established ethological characterization as subordinate to CD-1 mice in chronic social defeat stress (Berton et al., 2006; Krishnan et al., 2007; Golden et al., 2011). Additionally, aggressive CD-1 residents form a CPP to C57 intruder-paired contexts where aggression has occurred (Golden et al., 2016, 2017b; Aleyasin et al., 2018b), and readily self-administer for aggressive interactions (Golden et al., 2017a).

We gave all mice ad libitum access to standard food chow and water in all experiments. Following genotyping, we singly-housed all experimental mice with enrichment (cotton padding only) in standard clearpolycarbonate cages covered with stainless-steel wire lids and maintained them on a reverse $12 \mathrm{~h}$ light/dark cycle (lights off at 8:00 A.M.). We group-housed (4 per cage) the non-experimental C57 intruder mice under identical housing conditions as the experimental mice. We performed all experiments in accordance with the Guide for the Care and Use of Laboratory Animals (Ed 8, 2011), under protocols approved by the local Animal Care and Use Committee.

\section{Apparatus}

We trained and tested all mice in standard Med Associates operant chambers, as previously described (Golden et al., 2017a). Each chamber was enclosed in a ventilated sound-attenuating cubicle and illuminated by one of two houselights, each positioned above two retractable levers on opposite sides of the chamber. These two retractable levers were designated "active" and a third nonretractable lever was designated "inactive"; all levers were positioned $2.4 \mathrm{~cm}$ above the grid floor. Presses on one active lever (only extended during food self-administration) resulted in delivery of $20 \mathrm{mg}$ food pellets and a $2 \mathrm{~s}$ light cue (bright yellow LED), whereas presses on the other, oppositely positioned active lever (only extended during aggression self-administration) resulted in the delivery of a subordinate male C57 intruder and a $2 \mathrm{~s}$ tone cue $(2900 \mathrm{~Hz}, 20 \mathrm{~dB}$ above background). We presented the intruder through an automatic guillotine-style door adjacent to the active lever.

To facilitate intruder presentation, we attached a custom-made 3Dprinted two-level intruder chamber to each operant behavior box; the chamber housed the intruders during self-administration sessions. Each level within the chamber contained one male subordinate C57 intruder, such that the intruder on the lower level was always immediately available to the resident upon successful completion of the operant response. Upon completion of the reinforcement-schedule requirement and presentation of the conditioned tone cue, the automatic guillotine door 
opened vertically for $10 \mathrm{~s}$ and we guided the lower-level intruder into the operant box via a sliding rear wall, which also prevented either the resident or intruder mouse from moving back into the intruder chamber while the automatic door was open. After the door closed, we loaded the second, upper-level intruder into the emptied lower level through a sliding floorboard in preparation for the next trial. We removed the intruder mice from the operant box through the side door of the main operant chamber.

\section{Immunohistochemistry}

Immediately after the behavioral tests (60 min after start of the session), we anesthetized the mice with isoflurane and perfused them transcardially with $\sim 100 \mathrm{ml}$ of $0.1 \mathrm{M} \mathrm{PBS}, \mathrm{pH} 7.4$, followed by $\sim 400 \mathrm{ml}$ of $4 \%$ paraformaldehyde (PFA) in PBS. We removed the brains and postfixed them in $4 \%$ PFA for $2 \mathrm{~h}$ before transferring them to $30 \%$ sucrose in PBS for $48 \mathrm{~h}$ at $4^{\circ} \mathrm{C}$. We froze the brains in dry ice and stored them at $-80^{\circ} \mathrm{C}$. We cut coronal sections $(40 \mu \mathrm{m})$ of the ventral striatum using a Leica cryostat.

For Fos immunolabeling (Experiment 1) and Fos colocalization with DREADD expression (Experiment 4), we selected series of sections from approximate bregma levels of $+1.70-0.98 \mathrm{~mm}$ (Franklin and Paxinos, 2013). We rinsed free-floating sections in PBS $(3 \times 10 \mathrm{~min})$, incubated for $2 \mathrm{~h}$ in $10 \%$ normal horse serum (NHS) in $0.5 \%$ PBS-Tx, and incubated the sections for $48 \mathrm{~h}$ at $4{ }^{\circ} \mathrm{C}$ with primary antibody in $2 \%$ NHS and 0.5\% PBS-Tx. For Experiment 1, we used rabbit anti-Fos (1:1000; Cell Signaling Technology, Phospho-Fos, 5348S; RRID:AB_10013220), and for Experiment 4, we used rabbit anti-Fos (1:1000; Cell Signaling Technology, Phospho-Fos, 5348S; RRID:AB_10013220) and mouse antimCherry (1:1000; Living Colors, mCherry Monoclonal Antibody; RRID: AB_2307319). We rinsed the sections in PBS $(3 \times 10 \mathrm{~min})$ and incubated them for $4 \mathrm{~h}$ with a secondary antibody in $2 \%$ NHS in $0.5 \%$ PBS-Tx. For Experiment 1, we used biotinylated donkey anti-rabbit AlexaFluor 594 (1:500; Jackson Immuno Research, 711-585-152; RRID:AB_2340621). Note that we show all Fos IHC in green across figures for consistency. For Experiment 4, we used biotinylated mouse anti-rabbit AlexaFluor 488 (1:500; Jackson ImmunoResearch, 211-545-109; RRID:AB_2339168) and biotinylated anti-mouse AlexaFluor 594 (1:500, Jackson ImmunoResearch, 715-585-150; RRID:AB_2340854). We rinsed the sections three times in PBS $(3 \times 10 \mathrm{~min})$ and mounted them onto gelatin-coated glass slides, air-dried, and coverslipped the sections with VECTASHIELD with DAPI (Vector Laboratories). We used an EXi Aqua camera (QImaging) attached to a Zeiss Axio Scope Imager M2 using iVision (4.0.15 and 4.5.0, BioVision Technologies) to collect and analyze the images. We captured each image using a $5 \times($ Experiment 1$)$ or a $10 \times($ Experiment 4$)$ objective. We quantified the total number of Fos-positive cells for the NAc shell and core subregions. We performed the image-based quantification in a blind manner (mean inter-rater reliability between S.A.G. and M.J., $r=0.89$ ).

\section{RNAscope ISH assay}

We performed RNAscope ISH for Fos, Drd1, and Drd2 mRNAs as described previously (Li et al., 2015; Caprioli et al., 2017; Venniro et al., 2017). Sixty minutes after the beginning of the test session, we briefly anesthetized the mice with isoflurane $(<30 \mathrm{~s})$ and decapitated them. We rapidly extracted and froze their brains for $20 \mathrm{~s}$ in isopentane at $-40^{\circ} \mathrm{C}$. We stored the brains at $-80^{\circ} \mathrm{C}$ until use. We then collected ventral striatum coronal sections $(16 \mu \mathrm{m})$ directly onto Superfrost Plus slides (Fisher Scientific). We used an RNAscope Multiplex Fluorescent Reagent Kit (Advanced Cell Diagnostics) and performed the ISH assay according to the user manual for fresh-frozen tissue and as described previously (Rubio et al., 2015). On the first day, we fixed the brain slices in $10 \%$ neutral buffered formalin (Fisher Scientific) for $20 \mathrm{~min}$ at $4^{\circ} \mathrm{C}$. We rinsed the slices three times in PBS and dehydrated the slices in 50, 70, 100, and $100 \%$ ethanol. We stored the slices in fresh $100 \%$ ethanol overnight at $-20^{\circ} \mathrm{C}$. On the second day, we first dried the slides at room temperature for $10 \mathrm{~min}$. To limit the spreading of the solutions, we drew a hydrophobic barrier on the slides around the brain slices. We then treated the slides with protease solution (pretreatment 4) at room temperature for $20 \mathrm{~min}$ and then washed it off. We then applied target probes for Fos, Drd1, and
$\operatorname{Drd} 2$ to the slides and incubated them at $40^{\circ} \mathrm{C}$ for $2 \mathrm{~h}$ in an HybEZ oven. Each RNAscope target probe contains a mixture of $20 \mathrm{ZZ}$ oligonucleotide probes that are bound to the target RNA, as follows: Fos-C3 probe (GenBank accession NM_022197.2; target nt region, 473-1497), Drd1-C1 probe (GenBank accession NM_012546.2; target nt region, 104-1053), and Drd2-C2 probe (GenBank accession NM_012547.1; target nt region, 445-1531). Next, we incubated the slides with preamplifier and amplifier probes (AMP1, $40^{\circ} \mathrm{C}$ for $30 \mathrm{~min}$; $\mathrm{AMP} 2,40^{\circ} \mathrm{C}$ for $15 \mathrm{~min}$; $\mathrm{AMP} 3,40^{\circ} \mathrm{C}$ for $30 \mathrm{~min}$ ). We then incubated the slides with fluorescent-labeled probes by selecting a specific combination of colors associated with each channel, as follows: green (AlexaFluor $488 \mathrm{~nm}$ ), orange (AlexaFluor $550 \mathrm{~nm}$ ), and far red (AlexaFluor $647 \mathrm{~nm}$ ). We used AMP4 Alt4 to detect triplex Fos, Drd1, and $D r d 2$ in far red, green, and red channels. Finally, we incubated the slides for $20 \mathrm{~s}$ with DAPI. We washed the slides with one washing buffer two times in between incubations. After air drying the slides, we coverslipped them with a VECTASHIELD fluorescent mounting medium $(\mathrm{H}-$ 1400, Vector Laboratories). We captured fluorescent images of labeled cells in NAc shell and core using an ORCA-Flash4.0 Digital camera (Hamamatsu, C11440-42U30) attached to a Zeiss Axio Scope Imager M2 using Micro-Manager 1.4 software (Open Imaging) using a $20 \times$ objective (Carl Zeiss Microscopy). We performed the image capture and quantification in a blind manner (inter-rater reliability between M.V. and M.J., $r=0.88)$.

\section{Intracranial surgeries and histology}

We performed surgeries under aseptic conditions. We anesthetized the mice with isoflurane (Butler Schein; 5\% induction, 3\% maintenance) and positioned them into a stereotaxic frame (David Kopf Instruments). Using 33-gauge syringe needles (Hamilton), we bilaterally injected a given virus at $100 \mathrm{nl} \cdot \mathrm{min}^{-1}$ for $5 \mathrm{~min}(500 \mathrm{nl})$ targeting the NAc shell (bregma: AP +1.6 ML, $\pm 1.5 \mathrm{ML},-4.4 \mathrm{DV} ; 10^{\circ}$; Franklin and Paxinos, 2013), and then removed the needle after $5 \mathrm{~min}$. We injected pAAV8hSyn-DIO-hM4D(Gi)-mCherry (Addgene 44362-AAV8; Lot v4479; $4.3 \times 10^{12} \mathrm{GC} / \mathrm{ml}$ ) or pAAV8-hSyn-DIO-mCherry (Addgene 50459AAV8; Lot v4481; $4.1 \times 10^{12} \mathrm{GC} / \mathrm{ml}$ ). We allowed the mice to recover for at least 1 week before aggression self-administration training.

At the completion of the experiments, we deeply anesthetized the mice in a chamber with isoflurane vapor for $90 \mathrm{~s}$, transcardially perfused them with $10 \mathrm{ml} \mathrm{PBS}$ followed by $20 \mathrm{ml}$ of $4 \%$ PFA, pH 7.4. We extracted the brains and fixed them for $24 \mathrm{~h}$ in $4 \%$ PFA and then transferred them to a $30 \%$ sucrose solution for $\sim 2 \mathrm{~d}$. We coronally sectioned the brains $(40 \mu \mathrm{m})$ on a cryostat (Leica) and imaged them with an epifluorescent microscope (Axio Imager.M2, Zeiss) using a $5 \times$ objective (Carl Zeiss Microscopy).

\section{Drug dose determination and administration}

We used a low dose of clozapine (Sigma-Aldrich) as our pharmacological agent to activate hM4Di. We dissolved clozapine in 100\% DMSO and then brought the solution to the final concentrations $(0.0,0.1,0.2$, or 1.0 $\mathrm{mg} / \mathrm{ml}$ ) by diluting the stock with sterile water until the solution reached $10 \%$ DMSO by volume. We used $10 \%$ DMSO as the vehicle. We injected vehicle or clozapine $(0.1,0.2$, or $1.0 \mathrm{mg} / \mathrm{kg}$, i.p) $20 \mathrm{~min}$ before testing.

We used clozapine instead of clozapine $N$-oxide $(\mathrm{CNO})$ because a recent study showed that clozapine, an atypical antipsychotic, is the active metabolite of $\mathrm{CNO}$ and that $\mathrm{CNO}$ is back-converted to clozapine in vivo before crossing the blood-brain barrier and binding to central DREADDs (Gomez et al., 2017). We performed a dose-response to find a behaviorally subthreshold clozapine dose. We tested dosages of $0,0.1$, 0.2 , and $1 \mathrm{mg} / \mathrm{kg}$ clozapine, and determined that a subthreshold dose of $0.1 \mathrm{mg} / \mathrm{kg}$ has no effect on operant responding for aggression selfadministration (see below)

\section{Experimental design}

\section{Aggression self-administration}

The aggression self-administration procedure is based on our previously published procedure (Golden et al., 2017a). Briefly, we gave resident mice three 5 min "magazine" training sessions in their operant chambers for access to aggression. Each session began with the presentation of the aggression-paired houselight followed 10 s later by both a $2 \mathrm{~s}$ tone cue and 
the immediate insertion of a C57 intruder mouse; the houselight remained on for the duration of the session and served as an aggressionpaired discriminative stimulus for the resident mouse. Next, we trained the resident mice to self-administer access to an intruder during $48 \mathrm{~min}$ daily sessions (see specific experiments in the following sections), using a discrete-trial design. Each 48 min session included twelve 4 min trials. The onset of the trials was signaled by the illumination of the aggressionpaired houselight, followed $10 \mathrm{~s}$ later by the insertion of the aggressionpaired active lever; we allowed the resident mice a maximum of $60 \mathrm{~s}$ to press the active lever on a fixed ratio 1 (FR1) reinforcement schedule before the lever automatically retracted.

Successful lever presses resulted in retraction of the active lever, followed first by a discrete $2 \mathrm{~s}$ tone cue and then the opening of the automatic guillotine door, through which we presented the intruder. The aggression-paired houselight remained illuminated for $130 \mathrm{~s}$, such that it terminated $120 \mathrm{~s}$ after the insertion of the active lever. We allowed the resident mice access to the intruder either until the first attack bout was initiated or until the houselight turned off, at which point we removed the intruder through the main chamber door. We randomized the intruder mice across blocks and days such that no consecutive lever presses were reinforced with the same intruder. After the termination of the aggression-paired houselight, a $110 \mathrm{~s}$ intertrial interval elapsed before the start of the next trial. We recorded the number of successful trials, the number of inactive lever presses, and whether a successful trial culminated in an attack bout by the resident. We trained two independent observers to identify attack behavior, using previously operationalized metrics (Golden et al., 2016, Golden et al., 2017a,b).

\section{Test for aggression seeking}

We tested all mice for aggression seeking (operationally defined as active lever responding under extinction conditions) in 15,30 , or 60 min test sessions. The aggression-paired houselight (discriminative stimulus) signaled the start of the session. The aggression-paired active lever was inserted $10 \mathrm{~s}$ later. Active lever presses caused the delivery of the aggression-paired conditioned cue, with a $10 \mathrm{~s}$ timeout period between cue presentations, but no aggression encounter. At the end of the session, the active lever retracted and the houselight was turned off. We performed the aggression seeking test during early abstinence (Day 1), because in a previous study we have observed stable responding in nonreinforced relapse tests during the first 2 weeks of forced or voluntary abstinence (Golden et al., 2017b).

\section{Food self-administration}

The self-administration procedure for food was like the one for aggression trial training, with the following exceptions, as previously described (Golden et al., 2017b). First, active lever presses under the FR1 reinforcement schedule led to the delivery of two $20 \mathrm{mg}$ "preferred" palatable food pellets (Calu et al., 2014; TestDiet, catalog \#1811142; 12.7\% fat, $66.7 \%$ carbohydrate, and $20.6 \%$ protein); we paired pellet deliveries with a $2 \mathrm{~s}$ discrete light cue. Second, before the trial-design training sessions for food, we gave the mice a $30 \mathrm{~min}$ magazine-training session and 1-2 once-daily $1 \mathrm{~h}$ sessions in which a single pellet delivery was reinforced under an FR1, 20 s timeout reinforcement schedule. For magazine training, we delivered two pellets non-contingently every 120 s, paired with a $2 \mathrm{~s}$ discrete light cue. The session began with the illumination of the food-paired houselight followed $10 \mathrm{~s}$ later by the first pellet delivery and the discrete light cue; the food-paired houselight remained on for the duration of the session and served as a discriminative stimulus for the palatable food. At the end of the session, the houselight was turned off. The sessions began with the illumination of the food-paired houselight followed $10 \mathrm{~s}$ later by the insertion of the food-paired active lever. The food-paired houselight was turned off and active lever retracted at the end of the session. We used the preferred TestDiet pellet type, because in preference tests, both mice (Golden et al., 2017b) and rats (Pickens et al., 2012; Calu et al., 2014) prefer this pellet over pellets with different compositions and flavors. Furthermore, rats strongly prefer these pellets over intravenous methamphetamine or heroin (Caprioli et al., 2015; Venniro et al., 2017, 2018) and mice will preferentially choose these pellets over aggression self-administration (Golden et al., 2017a). These pellets allow for acquisition of food self-administration without any food deprivation.

\section{Resident-intruder test}

Each screening session consisted of placing one intruder into the home cage of a resident mouse for 5 min under dim light conditions. In the social defeat literature (Kudryavtseva et al., 1991; Berton et al., 2006; Krishnan et al., 2007) and in our own experience (Golden et al., 2011, 2016), younger smaller subordinate intruders do not aggress back on larger residents. In Experiment 3, we paired younger 6- to 8-week-old C57BL/6J intruders with 16-week-old larger D1-Cre (+) and D1-Cre (-) residents and performed the resident-intruder assay for 5 consecutive days. In Experiment 4, we paired a 12-week-old smaller D1-Cre $(+)$ and D2-Cre (+) F1 hybrid intruders with larger 4- to 6-month-old CD-1 resident during a single acute resident-intruder session. In Experiment 3, we manually recorded the latencies to the first attack bout. In the absence of an attack, we scored latency as $300 \mathrm{~s}$ (maximum duration of the session).

\section{Specific experiments}

Experiment 1: effect of aggression self-administration and aggression seeking on Fos expression in the NAc core and shell The purpose of Experiment 1 was to assess the expression of the immediate early gene marker Fos, a neural activity marker (Morgan and Curran, 1991; Cruz et al., 2013), in the NAc shell and core subregions following aggression self-administration and aggression seeking. We used an experimental design that included the between-subjects factor of Group: self-administration test, aggression seeking test, no-test control. We trained $18 \mathrm{CD}-1$ mice for aggression self-administration for $9 \mathrm{~d}$. We excluded three "non-aggressive" mice (data not shown) that either did not attack during magazine training or attacked on-average $<2$ times per session during the self-administration training period. We then separated the mice into the experimental groups (self-administration test, $n=5$; aggression-seeking test, $n=5$; no-test control, $n=5$ ). After training, we tested the self-administration group for aggression selfadministration and perfused the mice $60 \mathrm{~min}$ after the start of the session. We then tested the control and aggression seeking groups on abstinence Day 1 . We perfused the aggression seeking group mice $60 \mathrm{~min}$ after the start of testing and, on the next day, we perfused no-test control mice immediately from their home cages. Following tissue slicing and preparation, we immunohistochemically stained for Fos.

\section{Experiment 2: effect of aggression self-administration and} aggression seeking on Fos colocalization with Drd1 and Drd2 $m R N A$ expression in the NAc core and shell

The purpose of Experiment 2 was to compare Fos colabeling with Drd1and Drd2-expressing neurons in the NAc shell and core subregions with ISH after aggression self-administration and aggression seeking. We used an experimental design that included the between-subjects factor of experimental group: self-administration test, aggression seeking test, and no-test control. We first separated no-test controls $(n=5)$ from a cohort of 24 CD-1 mice. We then trained the remaining 19 CD-1 mice for aggression self-administration for $9 \mathrm{~d}$. We excluded nine non-aggressive mice that either did not attack during magazine training or attacked on-average $<2$ times per session during the self-administration training period. We separated the remaining mice to two experimental groups (self-administration test, $n=5$; aggression-seeking test, $n=5$ ). During Day 9 of training, we perfused the self-administration group mice $60 \mathrm{~min}$ after the start of the session. The following day, we tested the aggressionseeking group mice for and perfused them $60 \mathrm{~min}$ after the start of testing. We perfused the no-test control mice immediately from their home cages.

Experiment 3: validation of transgenic F1 hybrid breeding strategy and chemogenetic DREADD approach

The purpose of Experiment 3 was to validate the developmental and behavioral phenotypes relevant to operant aggression self-administration and aggression seeking in our transgenic F1 hybrid mice. We followed weekly weight trajectories of CD-1 $(n=12), \mathrm{C} 57(n=12), \mathrm{D} 1-\mathrm{Cre}(+)$ hybrid $(n=$ $20)$, D1-Cre $(-)$ hybrid $(n=14), \mathrm{D} 2-\mathrm{Cre}(+)$ hybrid $(n=24)$, and D2- 
Cre $(-)$ hybrid $(n=21)$ mice from ages $6-12$ weeks. In the same D1-Cre $(+)$ $(n=17)$ and D1-Cre $(-)(n=14)$, we assessed for changes in attack latency in repeated resident-intruder assays over $5 \mathrm{~d}$. We excluded 3 D1-Cre (+) non-aggressive mice that did not attack once throughout the resident-intruder assays. We then trained the same mice on aggression self-administration for $7 \mathrm{~d}$. We excluded $4 \mathrm{D} 1-\mathrm{Cre}(+)(n=$ $13)$ and 3 D1-Cre $(-)(n=11)$ non-aggressive mice that either did not attack during magazine training or attacked on-average $<2$ times per session during the self-administration training period.

We also validated sustained aggression-self administration behavior following our intracranial surgical procedure. After self-administration training, we injected the D1-Cre(+) mice with AAV8-DIO-hM4DimCherry. After surgical recovery, we retrained mice $(n=12)$ for $6 \mathrm{~d}$ for aggression self-administration and tested for aggression seeking.

Finally, we performed within-subjects dose-response assay to find a behaviorally subthreshold clozapine dose in mice. After selfadministration training, we tested the D1-Cre $(-)$ mice $(n=11)$ after injections of $0,0.1,0.2 \mathrm{mg} / \mathrm{kg}$ clozapine $20 \mathrm{~min}$ before the aggression self-administration sessions. We also tested a dose of $1.0 \mathrm{mg} / \mathrm{kg}$ with a subset of six mice but did not inject this dose to the other mice because of obvious sedative effects.

Experiment 4: validation of DREADD efficacy in D1- and D2-Cre F1 hybrids with Fos labeling

The purpose of Experiment 4 was to validate effectiveness of the AAV8DIO-hM4Di-mCherry virus at inhibiting neural activity in NAc D1- and D2-expressing neurons of our transgenic F1 hybrid mice using a clozapine dose of $0.1 \mathrm{mg} / \mathrm{kg}$. For both D1-Cre and D2-Cre hybrid mice, we used a $2 \times 2$ mixed factorial design that included the between-subjects factor of clozapine dose $(0,0.1 \mathrm{mg} / \mathrm{kg}$, i.p. $)$ and the within-subjects factor of virus (mCherry, hM4Di). We intracranially injected $12 \mathrm{D} 1-\mathrm{Cre}(+)$ hybrid and $11 \mathrm{D} 2-\mathrm{Cre}(+)$ mice with both AAV8-hSyn-DIO-mCherry (mCherry) and AAV8-hSyn-DIO-h4MDi-mCherry (h4MDi) into the NAc. We counterbalanced the hemisphere of the virus injections. After histological analysis, we excluded one D1-Cre $(+)$ mouse and two D2-Cre $(+)$ mice due to off-target virus injections. Four weeks after viral injections, we used the $\mathrm{F} 1$ hybrid mice as intruders against larger 4- to 6-month-old male CD-1 residents in a single 5 min residentintruder assay, a behavioral assay that robustly increases Fos expression in the NAc (Nehrenberg et al., 2013). We injected vehicle or clozapine $(0.1 \mathrm{mg} / \mathrm{kg})$ to $\mathrm{D} 1-\mathrm{Cre}(+)(n=5-6$ per dose $)$ or D2$\mathrm{Cre}(+)(n=4-5$ per dose $)$ mice 20 min before the resident-intruder assay. We perfused all mice $60 \mathrm{~min}$ after the start of testing. Following tissue slicing and preparation, we immunohistochemically stained for Fos and mCherry.

\section{Experiment 5: effect of inhibition of Drd1-expressing MSNs in} $N A c$ on aggression self-administration and aggression seeking The purpose of Experiment 5 was to determine whether DREADDmediated inhibition of Drd1-expressing neurons in the NAc would decrease aggression self-administration and aggression seeking after $1 \mathrm{~d}$ of abstinence. We used a $2 \times 2$ mixed factorial design that included the between-subjects factor of Virus condition (mCherry, hM4Di) and the within-subjects factor of clozapine dose $(0,0.1 \mathrm{mg} /$ $\mathrm{kg}$, i.p.). On test days, we injected vehicle or clozapine $20 \mathrm{~min}$ before the sessions. This experiment was our first use of combining our transgenic hybrid breeding strategy with the DREADD-clozapine procedure. Therefore, to ensure reproducibility, we first tested two independent cohorts of mice that we injected with hM4Di into the NAc and ran at different times. We collapsed the two cohorts (total $n=20$ ) for the statistical analysis and data presentation, resulting in uneven group size between the hM4Di group and the mCherry group, where we used a typical sample size for control conditions in viral delivery behavioral studies of $n=8$.

We trained 67 D1-Cre(+) hybrid mice for aggression selfadministration for $5 \mathrm{~d}$. A subset of these mice were from the D1-Cre $(+)$ group in Experiment 4. We excluded 37 non-aggressive mice that either did not attack during magazine training or attacked on-average $<2$ times per session during the self-administration training period. We intracra- nially injected the remaining mice with hM4Di or mCherry, then retrained them on aggression self-administration for $3 \mathrm{~d}$ following at least 1 week of recovery. We retrained a subset of D1-hM4Di mice $(n=11)$ for food self-administration for $4 \mathrm{~d}$. Using a repeated measures design that included the within-subjects factor of Clozapine dose $(0,0.1 \mathrm{mg} / \mathrm{kg}$, i.p. $)$, we then tested the D1-hM4Di mice for food self-administration and food seeking (extinction conditions). Due to a technical error with the active lever, we excluded one mouse from the aggression seeking test; we also excluded 3 mice due to off-target virus injections.

Effect of clozapine on aggression self-administration. We tested two groups of mice (D1-mCherry $n=8$; D1-hM4Di $n=19)$ using aggression self-administration procedures identical to those used during training. The order of clozapine dose $(0,0.1 \mathrm{mg} / \mathrm{kg}$, i.p. $)$ was counterbalanced between self-administration test days. We performed $1 \mathrm{~d}$ of retraining for aggression self-administration between test days.

Effect of clozapine on aggression seeking. We retrained hybrid mice for $1 \mathrm{~d}$ after aggression self-administration testing and then returned the mice to their home cages for $24 \mathrm{~h}$ of abstinence. We counterbalanced the order of clozapine dose $(0,0.1 \mathrm{mg} / \mathrm{kg}$, i.p.). We performed $1 \mathrm{~d}$ of retraining on aggression self-administration between the test days. The duration of the test session ( $15 \mathrm{~min}$ ) in Experiments 5 and 6 was shorter than in the other experiments to minimize carryover effect because of extinction learning from the first to the second test.

Effect of clozapine on food self-administration and food seeking. We trained a subset of D1-hM4Di mice $(n=11)$ for food self-administration for $4 \mathrm{~d}$ before food self-administration testing. We counterbalanced the dose of clozapine $(0,0.1 \mathrm{mg} / \mathrm{kg}$, i.p.). After the food self-administration tests, we returned the D1-hM4Di mice $(n=10)$ to their home cages for $24 \mathrm{~h}$ of abstinence from food and then tested them for food seeking. We counterbalanced the dose of clozapine $(0,0.1 \mathrm{mg} / \mathrm{kg}$, i.p. $)$.

\section{Experiment 6: effect of inhibition of Drd2-expressing MSNs in} NAc on aggression self-administration and aggression seeking The purpose of Experiment 6 was to determine whether DREADDmediated inhibition of Drd2-expressing neurons in the NAc would decrease aggression self-administration and aggression seeking after $1 \mathrm{~d}$ of abstinence. The experimental design for Experiment 6 was identical to that of Experiment 5, except that we used D2-Cre $(+)$ hybrid mice to target Drd2-expressing neurons in the NAc for DREADD-mediated inhibition. We trained $67 \mathrm{D} 2$-hybrid mice for aggression selfadministration for $5 \mathrm{~d}$. We excluded 34 non-aggressive mice that either did not attack during magazine training or attacked on-average $<2$ times per session during the self-administration training period. We intracranially injected the remaining mice with hM4Di or-mCherry, and then retrained them for aggression self-administration for $3 \mathrm{~d}$ after at least 1 week of recovery. We tested two groups of mice (D2-mCherry, $n=12$; D2-hM4Di, $n=14$ ) using the aggression self-administration and aggression seeking test procedures described for Experiment 5. We excluded seven mice because of off-target virus injections.

\section{Statistical analysis}

We used factorial ANOVAs using SPSS (GLM procedure) or Prism. When we obtained significant main effects or interaction effects $(p<$ 0.05, two-tailed), we followed them up with post hoc univariate ANOVAs and Fisher PLSD tests. Because our multifactorial ANOVAs yielded multiple main and interaction effects, we only report significant effects that are critical for data interpretation. We indicate results of post hoc analyses by asterisks in the figures but do not describe them in the Results section. We indicate $p$ values $<0.001$ as $p<0.001$ and provide exact $p$ values for those $>0.001$. In Table 1-1 (available at https://doi.org/10.1523/ JNEUROSCI.2409-18.2019.t1-1), we present the complete statistical analyses and summary statistics of the study.

\section{Results}

\section{Experiment 1: effect of aggression self-administration and} aggression seeking on Fos expression in the NAc core and shell

In Experiment 1, we used Fos immunohistochemistry to compare the pattern of neural activity in the NAc shell and core 


\section{A Experimental timeline}

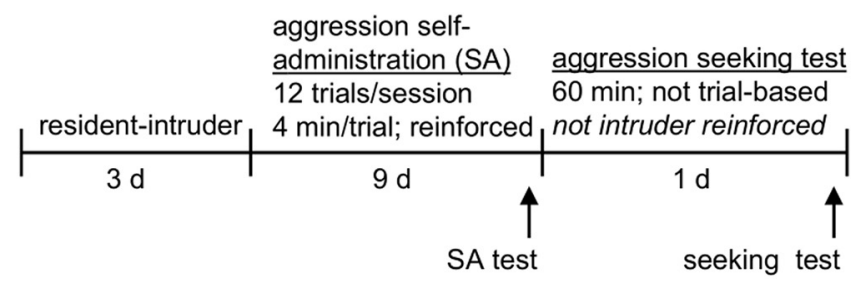

B Trial design

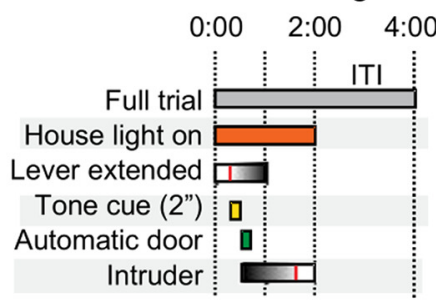

\section{Training D Aggression SA \\ E Aggression seeking \\ F Fos quantification}
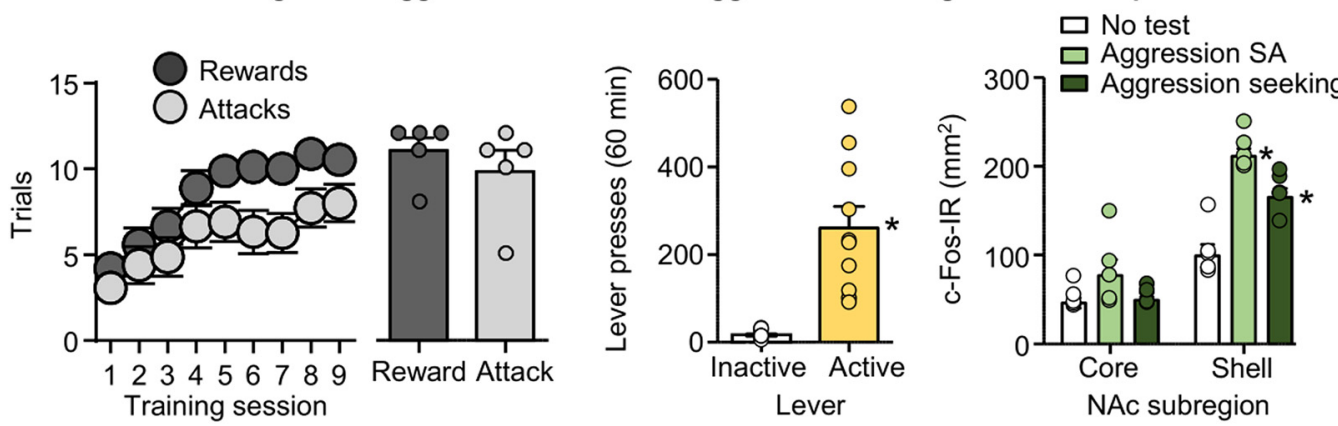

\section{G Fos IHC}

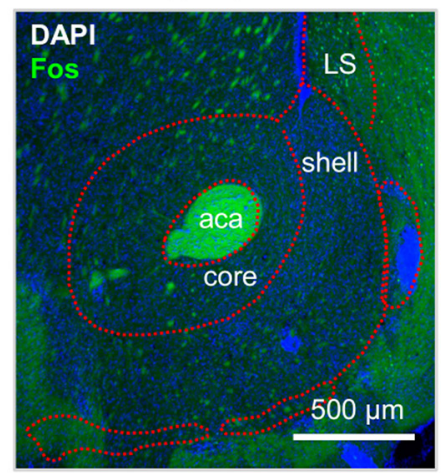

No test

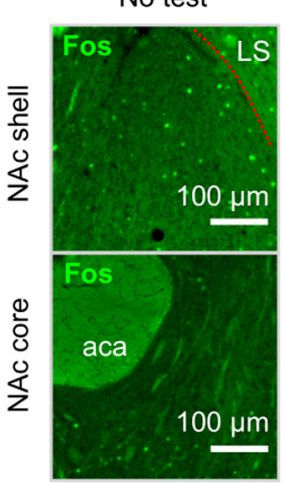

Aggression SA

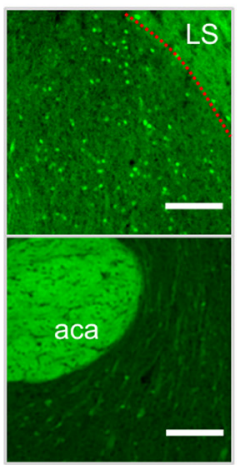

Aggression seeking

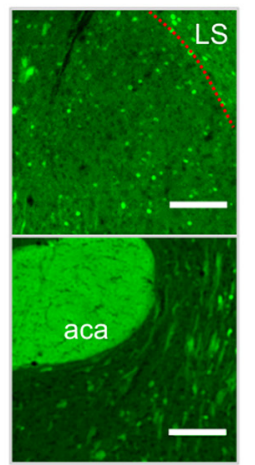

Figure 1. Aggression self-administration and aggression seeking caused higher Fos expression in NAc shell than core. $\boldsymbol{A}$, Timeline of Experiment $1 . \boldsymbol{B}, A$ schematic of a single self-administration trial. Vertical red lines within the "lever extended" and "intruder" bars indicate an active lever press and removal of an intruder after an attack bout, respectively, relative to total possible durations. C, Number of rewarded and attack trials over $9 \mathrm{~d}$ (48 min session/d) of aggression self-administration under an FR1 reinforcement schedule in CD-1 mice ( $n=15)$. Data are combined from all experimental groups (self-administration test, aggression seeking test, and control). $\boldsymbol{D}$, Number of reward and attack responses on the final day of training for the subset of mice that were included in the self-administration group during the self-administration test session $(n=5)$. $\boldsymbol{E}$, Number of active and inactive lever presses during a 60 min non-reinforced aggression seeking test $(n=10)$. $\boldsymbol{F}$, Fos-labeled cells (counts $/ \mathrm{mm}^{2}$ ) in the NAc core and shell subregions across experimental groups (self-administration test, aggression seeking test, and control). $\mathbf{G}$, Representative images of the NAc shell and core stained for Fos with DAPI (left). Representative images of Fos in the NAc shell or core across experimental groups (right). Data are mean \pm SEM. * Different from the control group, $p<0.01$. aca, Anterior commissure; LS, lateral septum.

subregions after tests for aggression self-administration and aggression seeking on abstinence Day 1 (Fig. $1 A, B$ ).

Self-administration training and aggression seeking CD-1 mice $(n=15)$ increased their self-administration over the $9 \mathrm{~d}$ training period based on number of rewarded trials per session $\left(F_{(8,112)}=62.7, p<0.001\right)$ and the number of attack trials, where an attack was made on an intruder $\left(F_{(8,112)}=7.2, p<\right.$ $0.001)$. The mice in the aggression seeking and control groups (total $n=10$ ) significantly pressed more on the active lever than on the inactive lever $\left(F_{(1,9)}=25.2, p=0.001\right.$; Fig. $\left.1 C-E\right)$.

Fos quantification

Exposure to both aggression self-administration and aggression seeking testing increased Fos expression in NAc shell but not core. The statistical analysis, which included the between-subjects factor of experimental group (self-administration test, aggression seeking test, no-test control) and the within-subjects factor of NAc subre- gion (core, shell) showed a significant interaction between the two factors $\left(F_{(2,12)}=21.8, p<0.001\right)$. Post hoc one-way ANOVAs showed a significant group effect for the shell $\left(F_{(2,12)}=26.7, p<\right.$ $0.001)$ but not core $\left(F_{(2,12)}=2.2, p=0.15\right.$; Fig. $\left.1 F\right)$.

Experiment 2: effect of aggression self-administration and aggression seeking on Fos colocalization with Drd1- and Drd2-MSNs in the NAc core and shell

In Experiment 2, we used RNAscope ISH to characterize Fos colocalization with Drd1 and Drd2 in NAc core and shell (Fig. 2A).

Self-administration training and aggression seeking

CD-1 mice $(n=10)$ increased their self-administration over the $9 \mathrm{~d}$ training period based on number of rewarded trials per session $\left(F_{(8,72)}=7.0, p<0.001\right)$. However, they did not increase number of attack trials, where an attack was made on an intruder $\left(F_{(8,72)}=1.1, p=0.40\right)$. The mice in the aggression-seeking 


\section{A Experimental timeline}

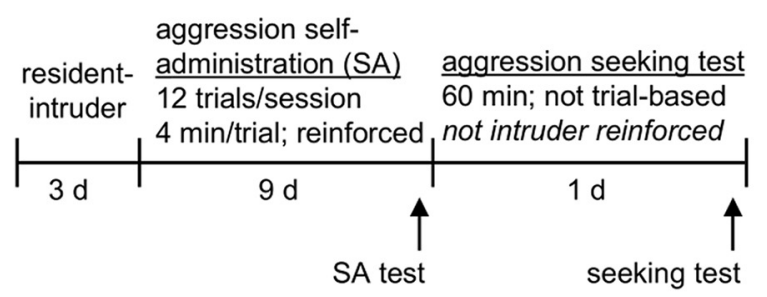

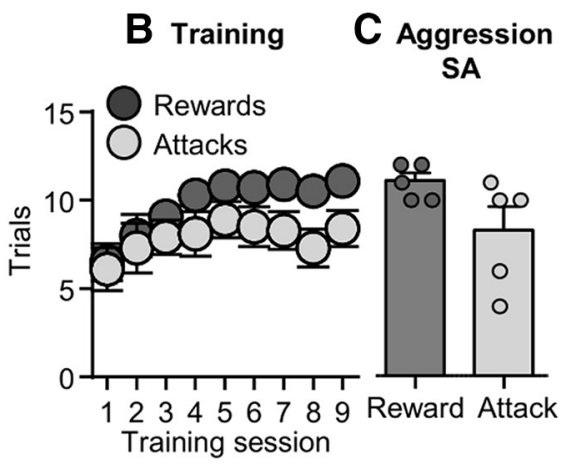

\section{E In situ hybridization}
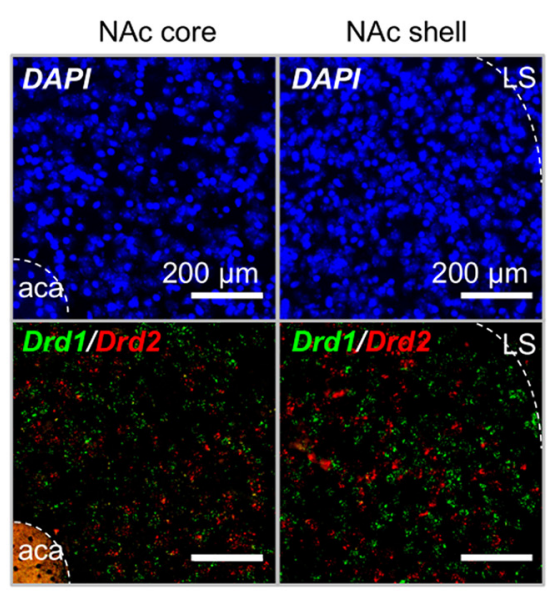

\section{G Fos quantification}

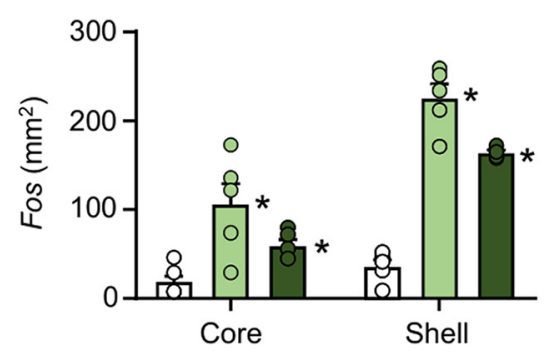

NAc subregion

\section{F Fos expression in Drd1 and D2-expressing neurons in NAc core and shell}
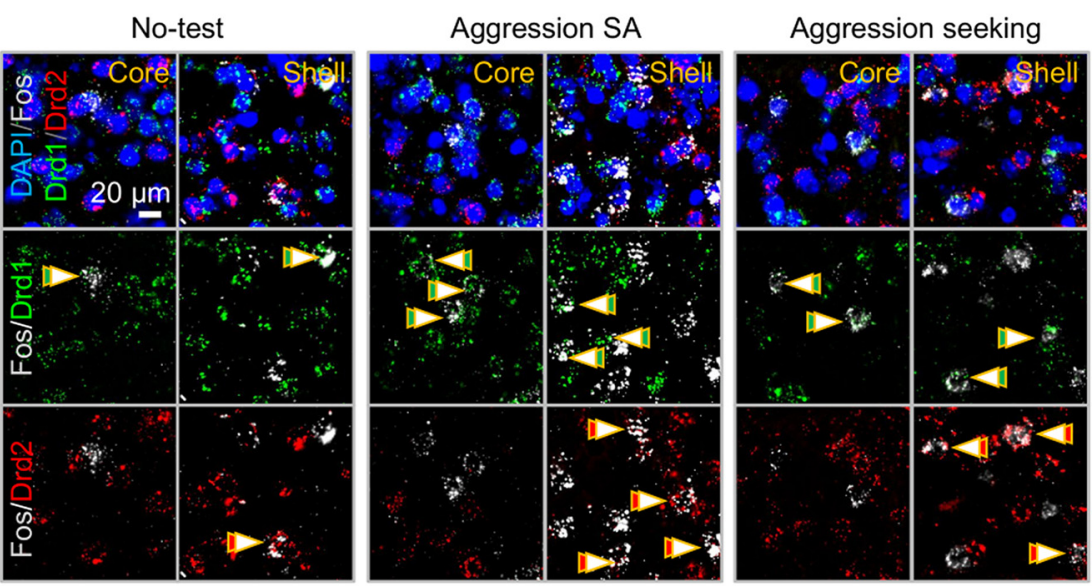

\section{H Double-labelled cells quantification}
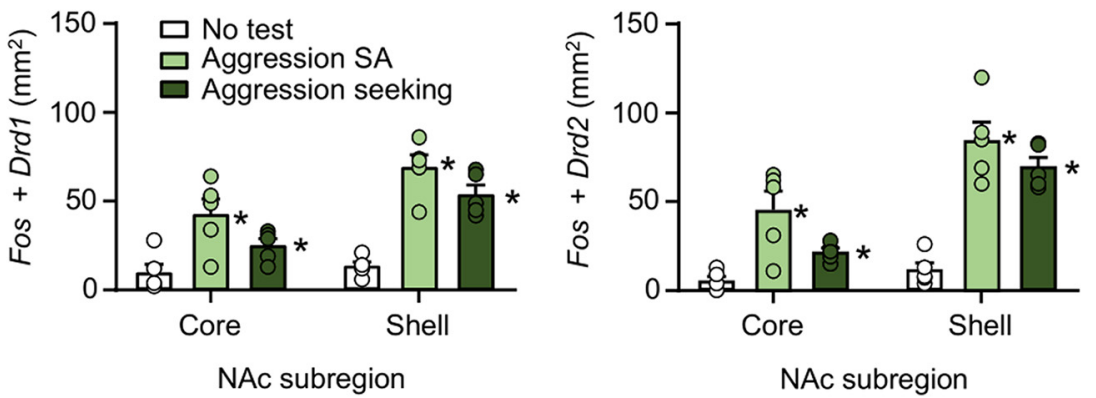

Figure 2. Aggression self-administration and aggression seeking increased Fos expression in the NAc core and shell Drd1- and Drd2-expressing neurons. $\boldsymbol{A}$, Timeline of Experiment 2. $\boldsymbol{B}$, Number of rewarded and attack trials over $9 \mathrm{~d}$ (48 min session/d) of aggression self-administration under an FR1 reinforcement schedule in CD-1 mice ( $n=10)$. Data are combined from aggression self-administration and aggression seeking experimental groups. $\boldsymbol{C}$, Number of reward and attack responses on the final day of training for the subset of mice that were included in the self-administration group during the self-administration test $(n=5)$. $\boldsymbol{D}$, Number of active and inactive lever presses during a 60 min aggression seeking test in the aggression-seeking group ( $n=$ 5). $\boldsymbol{E}$, Representative images of the NAc shell and core stained for DAPI (top), Drd1, and Drd2 mRNA (bottom) using ISH. $\boldsymbol{F}$, Representative images of the NAc shell or core, stained for Fos, Drd1, Drd2 mRNA, and DAPI across experimental groups (self-administration test, aggression-seeking test, and no-test control). G, Fos-labeled cells (cells/mm ${ }^{2}$ ) in the NAc core and shell subregions across experimental groups. $\boldsymbol{H}$, Counts of cells colabeled with Fos + Drd1 or Fos + Drd2 in the NAc core and shell across experimental groups. Data are mean \pm SEM. *Different from the no-test control group, $p<0.05$. aca, Anterior commissure; LS, lateral septum.

group $(n=5)$ pressed significantly more on the active lever than on the inactive lever $\left(F_{(1,4)}=30.8, p=0.005\right.$; Fig. $\left.2 B-D\right)$.

Fos: RNAscope

As in Experiment 1, exposure to aggression self-administration and aggression seeking testing caused higher Fos induction in NAc shell than in core. But unlike Experiment 1, both manipulations also increased Fos expression in the core. The statistical analysis, which included the between-subjects factor of Group (aggression self-administration, aggression seeking, no-test control) and the within-subjects factor of NAc subregion (core, shell) showed a significant interaction between the two factors
$\left(F_{(2,12)}=28.6, p<0.001\right)$. Post hoc one-way ANOVAs showed a significant group effect for both shell $\left(F_{(2,12)}=89.3, p<0.001\right)$ and core $\left(F_{(2,12)}=7.8, p=0.007\right.$; Fig. $\left.2 E-G\right)$.

Colocalization of Fos with Drd1 and Drd2

Exposure to aggression self-administration and aggression seeking testing increased Fos in both Drd1- and Drd2-expressing neurons in NAc core and shell. The statistical analysis of Fos, which included the between-subjects factor of experimental group (aggression self-administration test, aggression seeking test, no-test control), and the within-subjects factors of NAc subregion and cell-type (Drd1, Drd2) showed a significant interaction between 
A Breeding schematic

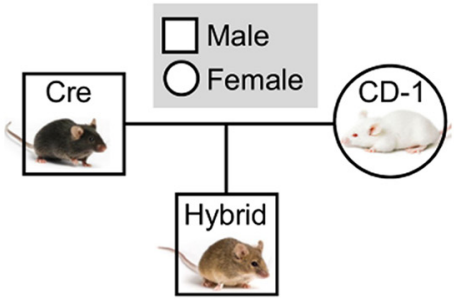

B Experimental timeline

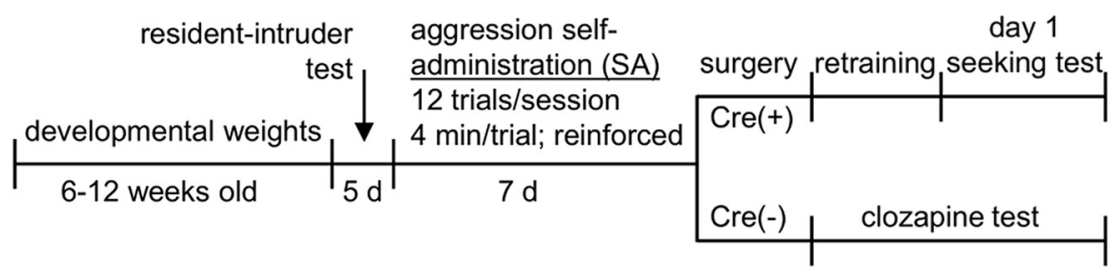

\section{Developmental weights}

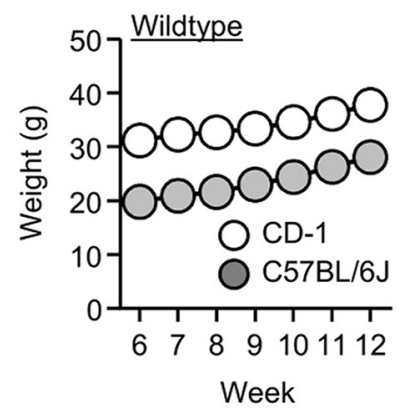

F Aggression SA retraining

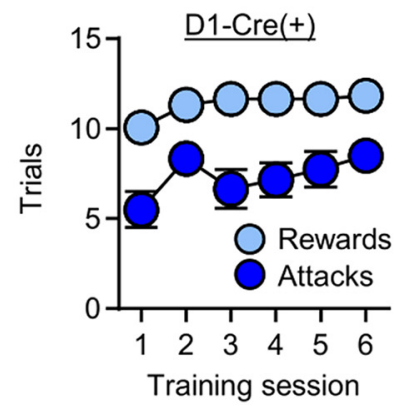

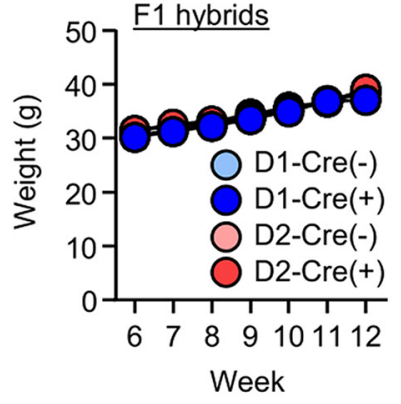

G Aggression seeking test

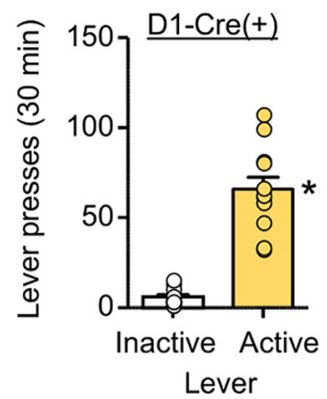

D Residence intruder latency

E Aggression SA
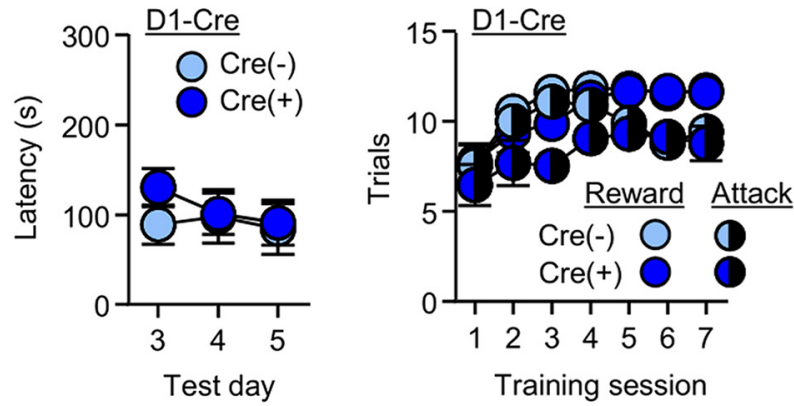

H Clozapine dose response

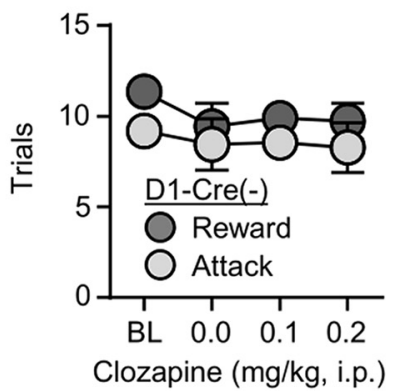

Figure 3. Validation of transgenic F1 hybrid breeding strategy and chemogenetic DREADD approach. A, A schematic of the breeding approach used to generate D1-Cre or D2-Cre F1 hybrid mice. B, Timeline of Experiment 3. C, Weekly developmental weights ( $g$ ) of CD-1 $(n=12)$ and C57 ( $n=12)$ mice from 6 to 12 weeks old (left). Weekly developmental weights of D1-Cre( -$)$ hybrid $(n=$ 14), D1-Cre( + ) hybrid ( $n=20)$, D2-Cre( -$)$ hybrid $(n=21)$, and D2-Cre( + ) hybrid $(n=24)$ mice (right). $\boldsymbol{D}$, Latency to attack (s) during the last 3 d of resident-intruder testing in D1-Cre( -$)(n=$ 14) and D1-Cre $+(n=17)$ mice. Mice were screened in resident-intruder assays over five consecutive days. $\boldsymbol{E}$, Number of rewarded and attack trials over $9 \mathrm{~d}$ ( $48 \mathrm{~min}$ session/d) of aggression self-administration under an FR1 reinforcement schedule in D1-Cre $(-)(n=11)$ and D1-Cre $(+)(n=13)$ mice. $F$, Number of rewarded and attack trials over $6 \mathrm{~d}$ of aggression self-administration retraining in D1-Cre( +$)$ mice $(n=12)$ following intracranial surgery. $\mathbf{G}$, Number of active and inactive lever presses during a 30 min aggression seeking test in in D1-Cre $(+)$ mice $(n=12)$ retrained for aggression self-administration. $\boldsymbol{H}$, Number of rewarded and attack trials during aggression self-administration tests after injection of $0.0,0.1$ or $0.2 \mathrm{mg} / \mathrm{kg}$ clozapine in D1-Cre $(-)$ mice $(n=11)$. Baseline rewards and attacks were averaged from the last $3 \mathrm{~d}$ of training. Data are mean \pm SEM. ${ }^{*}$ Different from the inactive lever, $p<0.05$.

group and NAc subregion $\left(F_{(2,12)}=13.5, p=0.001\right)$ and between NAc subregion and cell type $\left(F_{(1,12)}=6.6, p=0.024\right)$. However, there were no significant effects of cell type or additional interactions between cell type and the other two factors ( $p$ values $>0.05$; Fig. 2H).

Experiment 3: validation of transgenic F1 hybrid breeding strategy and chemogenetic DREADD approach

Developmental weights

We measured the weekly weights of CD-1 $(n=12)$ and C57 mice $(n=12)$ from ages 6 to 12 weeks old. Mice of both strains gained weight consistently over this time period and there was a significant difference in weights between CD-1 and C57 mice $\left(F_{(1,22)}=\right.$ $28.3, p<0.001)$. We also measured weights of D1-Cre $(-)$, D1Cre $(+)$, D2-Cre $(-)$, and D2-Cre $(+)$ F1 hybrid mice. The mice gained weight consistently over time and there were no differences in weight trajectory based on Cre genotype, positive or negative (week $\times$ Cre, $F_{(6,450)}=0.3, p=0.95$ ) or based on do- pamine receptor transgene strain, D1 or D2 (week $\times$ dopamine receptor subtype, $F_{(6,450)}=1.7, p=0.12$; Fig. $\left.3 A-C\right)$.

\section{D1-Cre $(+)$ and D1-Cre $(-)$ resident-intruder latencies}

In the same D1-Cre $(+)(n=17)$ and D1-Cre $(-)(n=14)$ mice, we measured attack latency during repeated resident-intruder tests across $5 \mathrm{~d}$. We analyzed latencies from Days 3-5 and found no differences in attack latency between the Cre genotypes $\left(F_{(1,29)}=0.3, p=0.59\right.$; Fig. $\left.3 D\right)$.

D1-Cre (+) and D1-Cre (-) self-administration training We then trained the same D1-Cre $(+)(n=13)$ and D1-Cre $(-)$ $(n=11)$ mice for aggression self-administration for $7 \mathrm{~d}$. The mice significantly increased their self-administration behavior over the $7 \mathrm{~d}$ training period based on number of rewarded trials per session $\left(F_{(6,132)}=13.9, p<0.001\right)$ and the number of attack trials, where an attack was made on an intruder $\left(F_{(6,132)}=3.3\right.$, $p=0.004)$. There were no differences between the Cre genotypes 


\section{B D1-Cre C D2-Cre}

\section{A Fos expression in D1-Cre and D2-Cre positive cells in NAC}
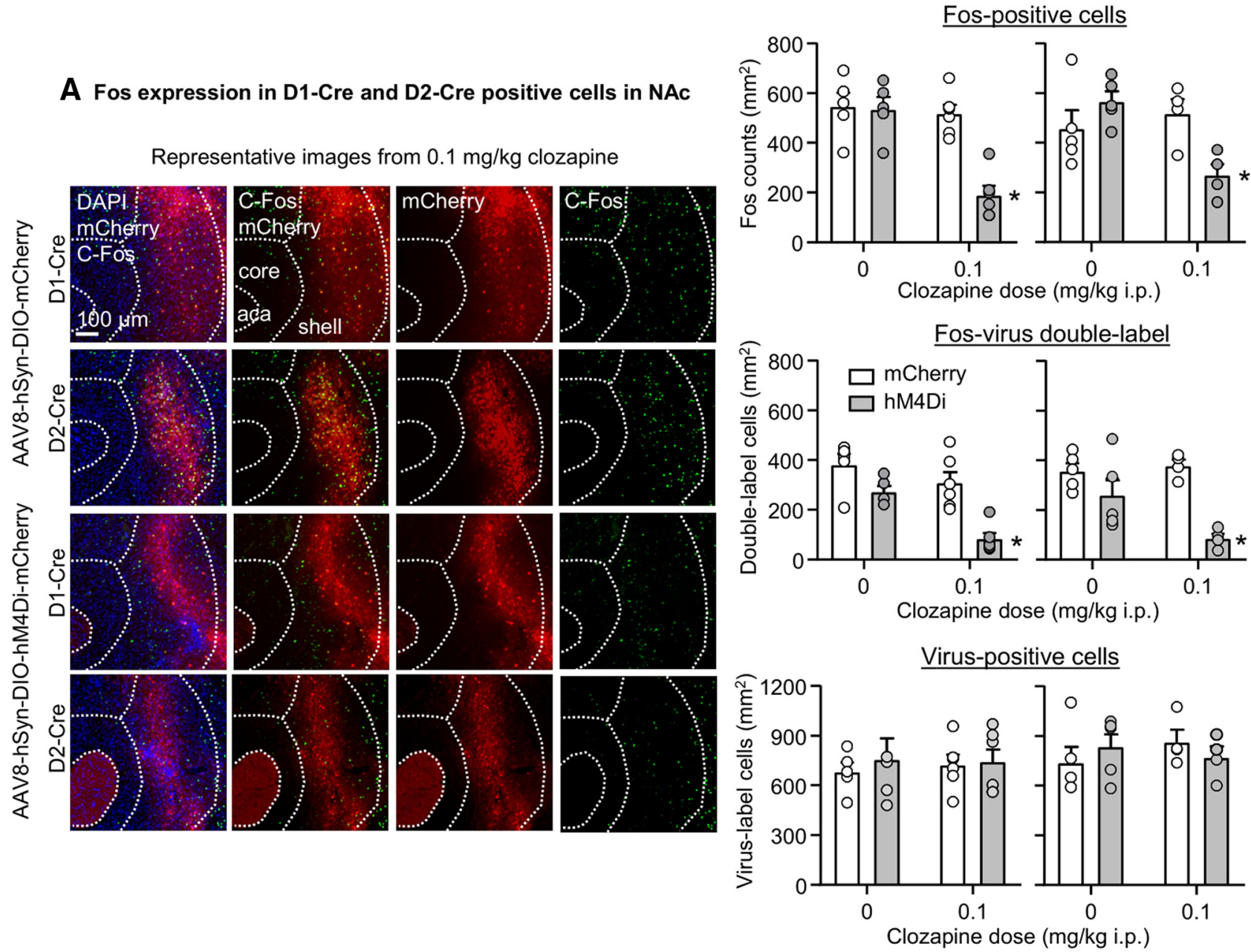

Figure 4. Validation of DREADD efficacy in D1- and D2-Cre F1 hybrids with Fos labeling. A, Representative images of Fos expression (right) and AAV8-DI0-hM4Di-mCherry and AAV8-DI0-mCherry viral infections (middle-right) in the NAC of D1-Cre and D2-Cre hybrid mice. Fos and mCherry images were merged (middle-left) and overlaid with DAPI (left). Mice underwent a single 5 min resident-intruder test before brain extraction. B, Density counts (cells $/ \mathrm{mm}^{2}$ ) of Fos (top), double-labeled Fos-virus cells (middle), and virus-positive cells (bottom) in the NAc of AAV8-DI0-hM4DimCherry or AAV8-DI0-mCherry hemispheres of D1-Cre mice. Mice were injected with vehicle $(n=5)$ or $0.1 \mathrm{mg} / \mathrm{kg}$ clozapine $(n=6)$. C, Density counts (cells $\left./ \mathrm{mm}^{2}\right)$ of Fos (top), double-labeled Fos-virus cells (middle) and virus-positive cells (bottom) in the NAc of AAV8-DI0-hM4Di-mCherry or AAV8-DI0-mCherry hemispheres of D2-Cre mice. Mice were injected with vehicle ( $n=5$ ) or 0.1 $\mathrm{mg} / \mathrm{kg}$ clozapine $(n=4)$. Data are mean \pm SEM. *Different from the other experimental conditions, $p<0.05$.

for the number of rewards $\left(F_{(1,22)}=1.1, p=0.31\right)$ or attacks $\left(F_{(1,22)}=3.1, p=0.09\right.$; Fig. $\left.3 E\right)$.

\section{D1-Cre $(+)$ postsurgery self-administration retraining and} aggression seeking

We assessed aggression self-administration for $6 \mathrm{~d}$ after intracranially injecting trained D1-Cre $(+)$ mice $(n=12)$ with hM4Di. The mice acquired aggression self-administration based on number of rewards $\left(F_{(5,55)}=3.7, p=0.006\right)$ and attacks $\left(F_{(5,55)}=2.5\right.$, $p=0.038)$. In the aggression seeking test, the mice also pressed significantly more on the active lever than the inactive lever $\left(F_{(1,11)}=76.0, p<0.001\right.$; Fig. $\left.3 F, G\right)$.

\section{D1-Cre(-) clozapine dose-response}

Using the same trained D1-Cre $(-)$ mice, we performed a doseresponse assay on clozapine doses of $0,0.1$, and $0.2 \mathrm{mg} / \mathrm{kg}$ and compared the number of rewards and attacks against baseline responding. We found no significant differences in responses of either rewards $\left(F_{(3,30)}=1.8, p=0.16\right)$ or attacks $\left(F_{(3,30)}=0.4\right.$, $p=0.75)$ across these doses from baseline. We conservatively chose $0.1 \mathrm{mg} / \mathrm{kg}$ as our behaviorally subthreshold clozapine dose for the subsequent DREADD experiments (Fig. $3 H$ ).

\section{Experiment 4: validation of DREADD virus efficacy in D1-} and D2-Cre F1 hybrids with Fos labeling

Fos and virus quantification in D1-Cre hybrid mice

Injections of clozapine selectively decreased Fos expression in the hM4Di but not mCherry-injected hemisphere (Fig. 4A,B). The statistical analysis of total Fos (Fig. $4 B$, top), which included the between-subjects factor of clozapine dose $(0,0.1 \mathrm{mg} / \mathrm{kg}$, i.p.) and the within-subjects factor of virus type (mCherry, hM4Di), showed significant effects of clozapine dose $\left(F_{(1,9)}=14.7, p=\right.$ $0.004)$, virus type $\left.F_{(1,9)}=19.6, p=0.002\right)$, and interaction of between the two factors $\left(F_{(1,9)}=17.1, p=0.003\right)$. A similar analysis restricted to Fos colabeled with mCherry or hM4Di (Fig. $4 B$, middle) showed significant effects of clozapine dose $\left(F_{(1,9)}=\right.$ $18.8, p=0.002)$ and virus type $\left(F_{(1,9)}=17.6, p=0.002\right)$, but no significant interaction between the two factors $\left(F_{(1,9)}=2.2, p=\right.$ 
0.17 ). There was no significant difference in viral infection (Fig. $4 B$, bottom).

Fos and virus quantification in D2-Cre hybrid mice Injections of clozapine selectively decreased Fos expression in the hM4Di but not mCherry-injected hemisphere (Fig. 4A,C). The statistical analysis of total Fos (Fig. $4 C$, top), which included the between-subjects factor of clozapine dose and within-subjects factor of virus type, showed a significant interaction of between the two factors $\left(F_{(1,7)}=11.7, p=0.011\right)$. A similar analysis restricted to Fos colabeled with mCherry or hM4Di (Fig. 4C, middle) showed significant effects of virus type $\left(F_{(1,7)}=22.9, p=\right.$ 0.002 ) and an interaction between virus type and clozapine dose $\left(F_{(1,7)}=5.8, p=0.047\right)$. There was no significant difference in viral infection (Fig. $4 C$, bottom).

Experiment 5: effect of inhibition of Drd1-expressing neurons in NAc on aggression self-administration and aggression seeking

In Experiment 5, we examined whether DREADD-mediated inhibition of Drd1-expressing neurons in the NAc would decrease aggression self-administration and aggression seeking on abstinence Day 1 (Fig. 5A).

\section{Self-administration training}

The D1-hybrid mice (D1-mCherry $n=8$; D1-hM4Di $n=19$ ) increased their self-administration over the training period based on number of rewarded trials per session $\left(F_{(10,250)}=25.8, p<\right.$ $0.001)$ and the number of attack trials, where an attack was made on an intruder $\left(F_{(10,250)}=7.2, p<0.001\right)$. There was no significant difference in acquisition of aggression self-administration between D1-mCherry and D1-hM4Di groups based on number of rewarded trials (virus type $\times$ session, $F_{(10,250)}=0.4, p=0.92$ ) and attack trials (virus type $\times$ session, $F_{(10,250)}=0.6, p=0.79$; Fig. 5B).

\section{Effect of clozapine on aggression self-administration}

We intracranially injected the mice with either hM4Di or mCherry, then retrained mice for $3 \mathrm{~d}$ for aggression self-administration until lever-pressing returned to its pre-surgery baseline. Clozapine significantly decreased aggression self-administration in hM4Di but not mCherry-injected mice. The statistical analysis, which included the between-subject factor of virus type and the within-subjects factor of clozapine dose showed a significant interaction between the two factors for both the number of rewarded trials $\left(F_{(1,25)}=11.5, p=\right.$ $0.002)$ and number of attack trials $\left(F_{(1,25)}=29.1, p<0.001\right.$; Fig. $\left.5 C\right)$.

Effect of clozapine on aggression seeking

After $1 \mathrm{~d}$ of retraining and after $24 \mathrm{~h}$ of abstinence in their home cages, we tested the mice for aggression seeking. Clozapine significantly decreased aggression seeking in hM4Di but not mCherryinjected mice. The statistical analysis, which included the betweensubjects factor of virus type and the within-subjects factors of clozapine dose and lever (active, inactive) showed a significant interaction between the three factors $\left(F_{(1,25)}=7.5, p=0.011\right)$. The triple interaction is because of a selective effect of clozapine on active versus inactive lever presses in the hM4Di-injected mice (Fig. 5D).

Effect of clozapine on food self-administration and food seeking The D1-hM4Di mice $(n=11)$ increased their self-administration over the training period based on number of rewarded pellets per session $\left(F_{(3,30)}=3.9, p=0.018\right)$ and showed a strong preference for the active food-paired lever over the inactive lever $\left(F_{(1,10)}=\right.$ 90.5, $p<0.001)$. Clozapine had no effect on either food selfadministration or food seeking after 1 abstinence day. For self- administration, there was no significant effect of clozapine on number of lever presses $\left(F_{(1,10)}=0.06, p=0.82\right)$ or number of rewarded pellets $\left(F_{(1,10)}=0.07, p=0.80\right)$. For food-seeking testing, clozapine had no effect on non-reinforced lever presses $\left(F_{(1,9)}=0.4, p=0.53\right.$; Fig. $\left.5 F, G\right)$.

Experiment 6: effect of inhibition of Drd2-expressing neurons in NAc on aggression self-administration and aggression seeking

In Experiment 6, we examined whether DREADD-mediated inhibition of Drd2-expressing neurons in the NAc would decrease aggression self-administration and aggression seeking (Fig. 6A).

\section{Self-administration training}

The mice (D2-mCherry $n=12$; D2-hM4Di $n=14$ ) increased their self-administration over the training period based on number of rewarded trials per session $\left(F_{(10,240)}=16.9, p<0.001\right)$ and the number of attack trials, where an attack was made on an intruder $\left(F_{(10,240)}=7.8, p<0.001\right)$. There were no significant differences in acquisition of aggression self-administration between the two groups based on number of rewarded trials (virus type $\times$ session, $F_{(10,240)}=1.2, p=0.28$ ) and attack trials (virus type $\times$ session, $F_{(10,240)}=1.6, p=0.121$; Fig. $\left.6 B\right)$.

\section{Effect of clozapine on aggression self-administration}

We intracranially injected the mice with either hM4Di or mCherry and then retrained them for $3 \mathrm{~d}$ on aggression selfadministration until lever-pressing returned to its pre-surgery baseline. Clozapine had no effect on aggression self-administration. The statistical analyses showed no significant interaction between virus and clozapine dose for the number of rewarded trials $\left(F_{(1,24)}=\right.$ $0.3, p=0.59)$ or the number of attack trials $\left(F_{(1,24)}=0.02, p=0.90\right.$; Fig. 6C).

\section{Effect of clozapine on aggression seeking}

After $1 \mathrm{~d}$ of retraining and after $24 \mathrm{~h}$ of abstinence in their home cages, we tested the mice for aggression seeking. Clozapine had no effect on aggression seeking, as indicated by lack of significant interaction between virus type $\times$ clozapine dose $\times$ lever $\left(F_{(1,24)}=0.03\right.$, $p=0.86$; Fig. $6 D)$.

\section{Discussion}

We studied the role of NAc Drd1- and Drd2-expressing neurons in aggression self-administration and aggression seeking. We found that inhibition of NAc Drd1- but not Drd2-expressing neurons decreased aggression self-administration and seeking. Aggression self-administration and seeking increased Fos expression to a greater degree in NAc shell than core and these manipulations induced Fos in Drd1- and Drd2-expressing neurons. We also validated a breeding strategy between outbred CD-1 mice and inbred C57-based Cre lines and a clozapine-based DREADD procedure that can be used to study cell-type mechanisms of aggression-seeking behaviors.

\section{Appetitive aggression reward in rodents}

There are eight publications on aggression self-administration in mice (Fish et al., 2002, 2005; Bannai et al., 2007; Couppis and Kennedy, 2008; May and Kennedy, 2009; Falkner et al., 2016; Golden et al., 2017a; Covington et al., 2018). Studies of the Miczek laboratory highlighted the complexity of GABAergic signaling by showing dose-dependent effects of the GABA(A)-positive modulator allopregnanolone: low doses increase operant responding with no effect on aggression severity, whereas higher doses have no effect on operant responding but increases aggression severity (Fish et al., 2002). 


\section{A Experimental timeline}

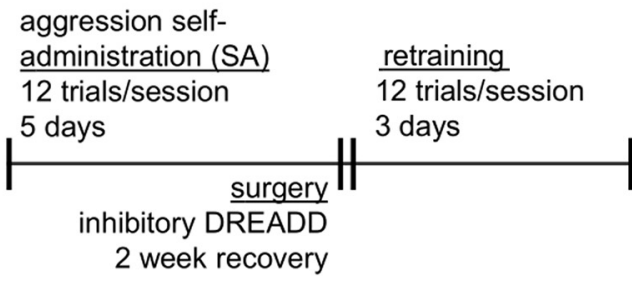

B D1-Cre hybrid aggression SA training

Rewards

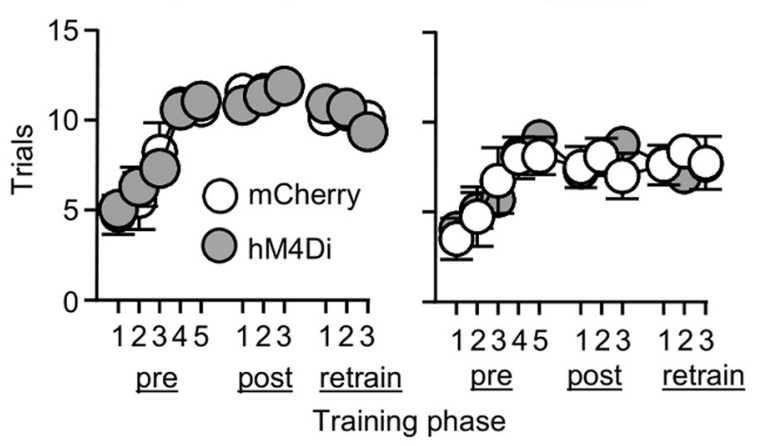

aggression SA test aggression seeking test

12 trials/session $15 \mathrm{~min}$; not trial-based

$4 \mathrm{~min} /$ trial; reinforced not intruder reinforced

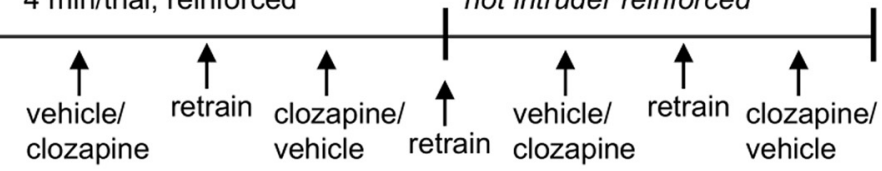

\section{D1-Cre hybrid aggression SA testing}

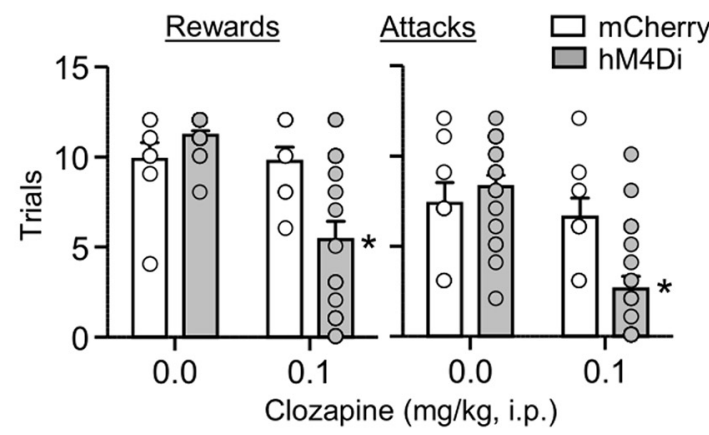

D D1-Cre hybrid aggression seeking test

E D1-Cre hybrid histology

AAV8-hSyn-

AAV8-hSyn-DIODIO-mCherry hM4Di-mCherry
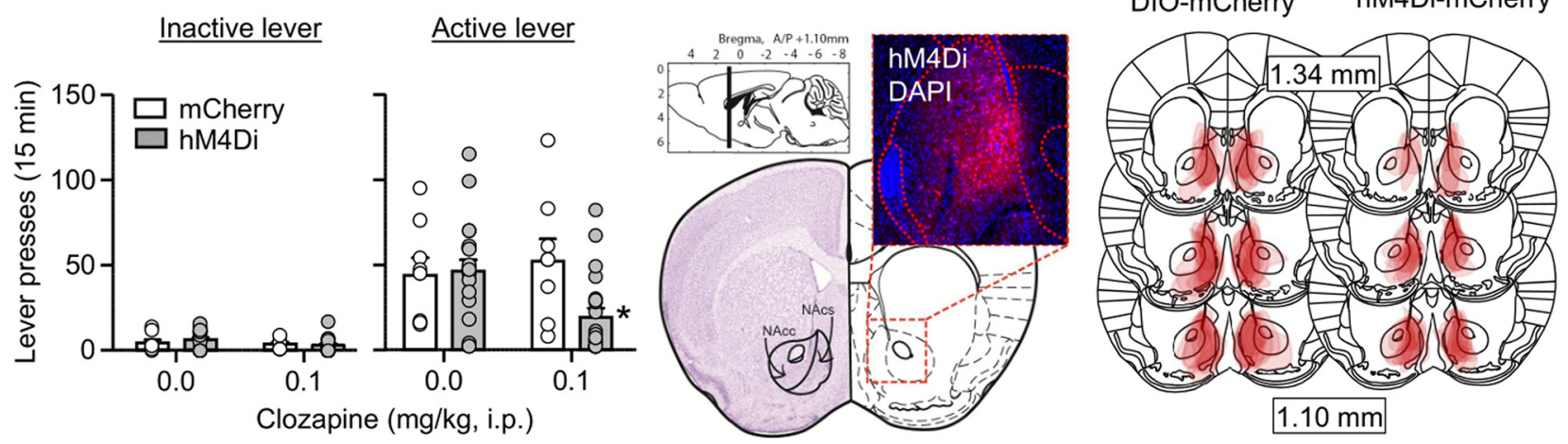

Palatable food

F D1-Cre hybrid food self-administration

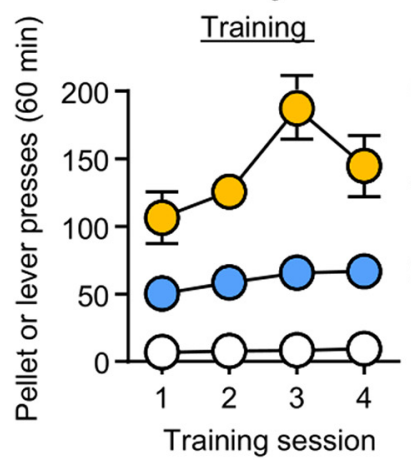

\section{Clozapine test}
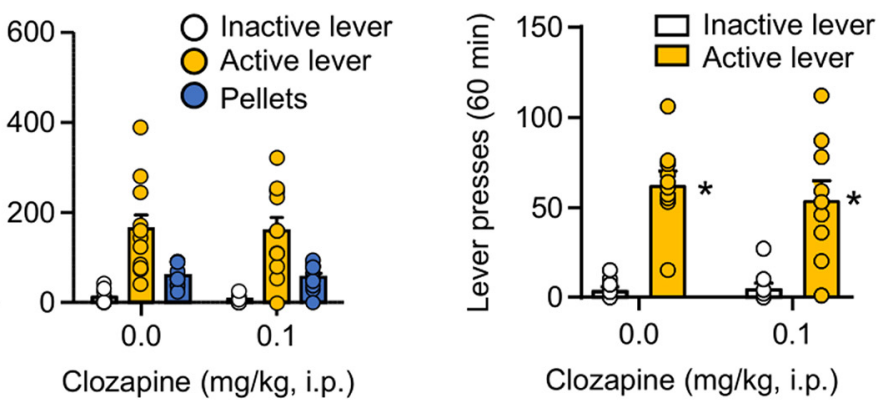

Figure 5. Inhibition of Drd1-expressing MSNs in NAc decreases aggression self-administration and aggression seeking. $\boldsymbol{A}$, Timeline of Experiment 5. $\boldsymbol{B}$, Number of rewarded (left) and attack (right) trials over $11 \mathrm{~d}$ (pre-surgery, postsurgery, test retrain; $48 \mathrm{~min}$ session/d) of aggression self-administration under an FR1 reinforcement schedule in D1-hM4Di $(n=19)$ and D1-mCherry $(n=$ 8) mice. C, Number of rewarded (left) and attack (right) trials during self-administration tests in D1-hM4Di and D1-mCherry mice. Mice were tested with both vehicle and $0.1 \mathrm{mg} / \mathrm{kg}$ of clozapine. $\boldsymbol{D}$, Number of active and inactive lever presses during $15 \mathrm{~min}$ aggression seeking tests in D1-hM4Di and D1-mCherry mice. Mice were tested with both vehicle and clozapine. $\boldsymbol{E}$, Representative image of the NAc in a D1-Cre mouse infected with AAV8-DI0-hM4Di-mCherry (with DAPI; left). Approximate placements of virus injections targeting the NAc and infection spread (right) in D1-hM4Di mice and D1-mCherry mice (mm from bregma; Franklin and Paxinos, 2013). F, A subset of D1-hM4Di mice $(n=11)$ were trained for food self-administration. Number of food rewards, active and inactive lever presses for $4 \mathrm{~d}$ ( $60 \mathrm{~min}$ session/d) of food self-administration under an FR1 reinforcement schedule (left). Mice tested with both vehicle and clozapine during food self-administration (right). $\mathbf{G}$, Number of active lever and inactive lever presses during $60 \mathrm{~min}$ food seeking tests in the D1-hM4Di mice. Data are mean \pm SEM. ${ }^{*}$ Different from vehicle, $p<0.05$. 


\section{A Experimental timeline}

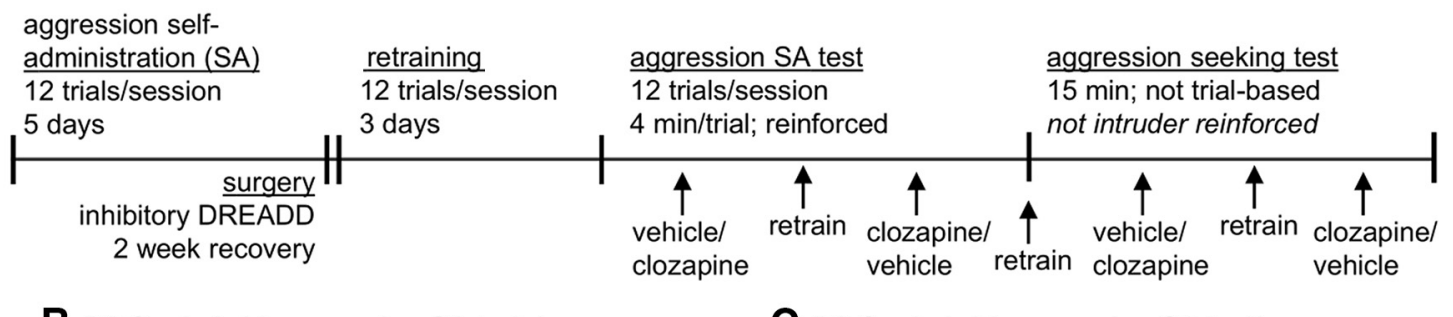

\section{B D2-Cre hybrid aggression SA training}

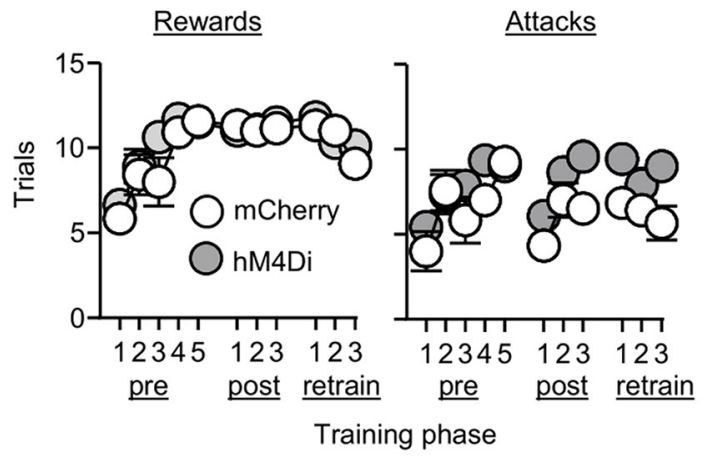

D D2-Cre hybrid aggression seeking test

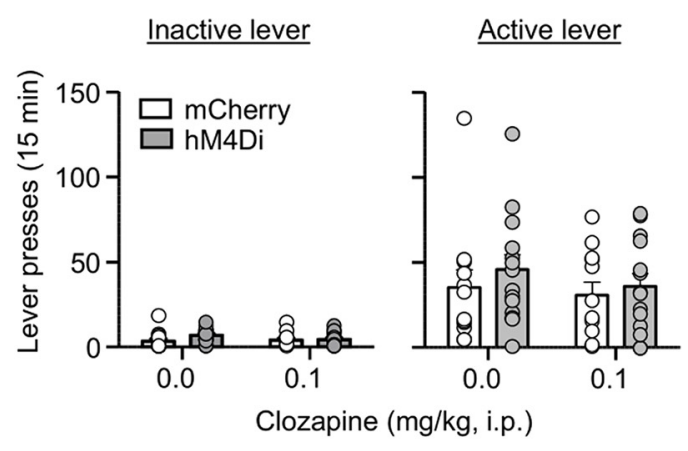

\section{D2-Cre hybrid aggression SA testing}

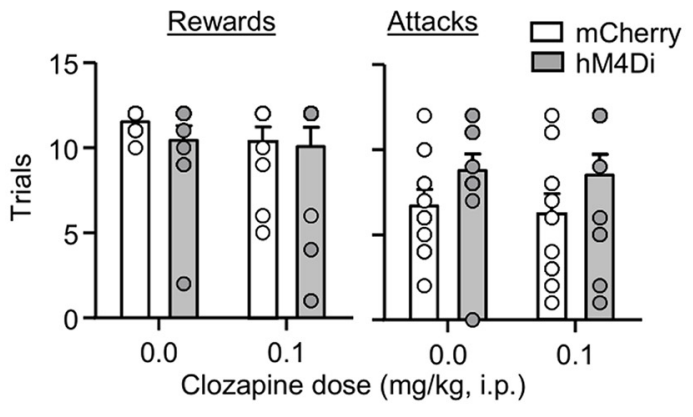

E D2-Cre hybrid histology

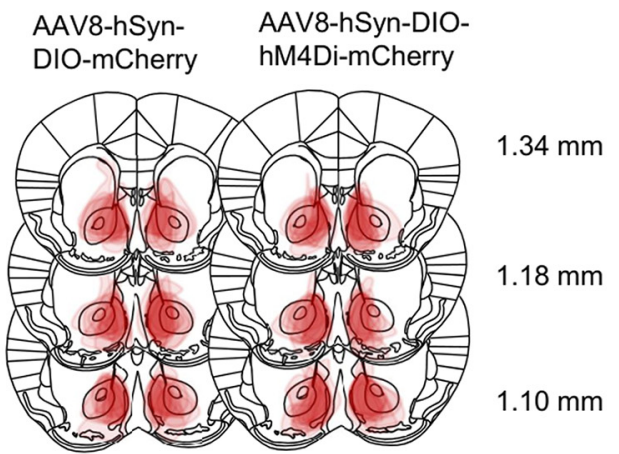

Figure 6. Inhibition of Drd2-receptor-expressing MSNs in NAc had no effect on aggression self-administration or aggression seeking. $\boldsymbol{A}$, Timeline of Experiment $6 . \boldsymbol{B}$, Number of rewarded (left) and attack (right) trials over $11 \mathrm{~d}$ (pre-surgery, postsurgery, test retrain; 48 min session/d) of aggression self-administration under an FR1 reinforcement schedule in D2-hM4Di ( $n=14$ ) and D2-mCherry $(n=12)$ mice. C, Number of rewarded (left) and attack (right) trials during self-administration tests in D2-hM4Di and D2-mCherry mice. Mice were tested with both vehicle and clozapine. $\boldsymbol{D}$, Number of active and inactive lever presses during 15 min aggression seeking tests in D2-hM4Di mice and D2-mCherry mice. Mice were tested with both vehicle and clozapine. $\boldsymbol{E}$, Approximate placements of virus injections targeting the NAc and infection spread in D2-hM4Di and D2-mCherry mice (mm from bregma; Franklin and Paxinos, 2013). Data are mean \pm SEM.

Aggression self-administration is also decreased by inhibition of corticosterone synthesis (Fish et al., 2005). These studies established that dissociative mechanisms can control learned operant aggression self-administration versus unconditioned aggression (attack).

Couppis et al. (2008) showed that NAc injections of Drd1- or Drd2-family antagonists (SCH23390 or sulpiride) decrease aggression self-administration. SCH23390 decreased operant responding but had a minimal effect on attack behavior, while sulpiride decreased both measures. However, the interpretation of these data is not straightforward, because local injections of sulpiride also decreased locomotor activity. Additionally, sulpiride binds to Drd3, Drd4, and $\alpha$-2 adrenoceptors (Boyajian and Leslie, 1987; Tang et al., 1994; Lawler et al., 1999), whereas SCH23390 binds to 5-HTR2c and 5-HTR2a (Briggs et al., 1991; Porter et al., 1999; Millan et al., 2001; Neumeyer et al., 2003). In this regard, NAc serotonin plays a role in social behavior (Dölen et al., 2013; Walsh et al., 2018) and reactive aggression (Nautiyal et al., 2015). Together, it cannot be ruled out that the results of Couppis et al. (2008) are because of sulpiride's effects on Drd3,
Drd4, or $\alpha-2$ adrenoceptors, or that SCH23390 effects are because of its effects on serotonin receptors.

Additional evidence for NAc dopamine's role in aggression reward is that in dominant rats, winning or anticipating aggressive encounters increases local extracellular dopamine levels (van Erp and Miczek, 2000; Ferrari et al., 2003). Furthermore, optogenetic stimulation of VTA, presumably leading to increased NAc dopamine release, increases aggressive bout severity in mice ( $\mathrm{Yu}$ et al., 2014). Additionally, the dopamine agonist methamphetamine increases aggressive behavior in rodents (Miczek, 1974; Miczek and Haney, 1994; Yu et al., 2014), whereas systemic injections of Drd1or Drd2-family antagonists decrease reactive aggression in residentintruder procedures (Kudryavtseva et al., 1999; Fragoso et al., 2016). In California mice, systemic injections of Drd1- and Drd2-family antagonists delay the emergence of a resident-intruder winner during repeated antagonistic encounters (Becker and Marler, 2015). These data indicate a role for both Drd1 and Drd 2 in reactive aggression. We speculate that the discrepancy between these data and our data on the selective role of NAc Drd1 but not Drd2 in appetitive 
aggression are because of the use of systemic pharmacology versus region- and cell-type-specific manipulations and mechanistic differences between reactive versus appetitive aggression.

Our present data and results from a recent study using aggression CPP, indicate differential involvement of NAc Drd1- and Drd2-expressing neurons in aggression reward. Aleyasin et al. (2018b) showed that $\Delta$ FosB selectively accumulates in Drd1expressing neurons after repeated aggressive encounters. $\Delta$ FosB is a truncated splice product of the FosB gene that is highly stable (Carle et al., 2007) and accumulates in NAc after repeated exposure to drugs, stress, and social environments (Robison and Nestler, 2011; Nestler, 2015). However, accumulation of $\Delta$ FosB in Drd1-expressing neurons promotes unconditioned reactive aggression in the resident-intruder task but not learned aggression CPP (Aleyasin et al., 2018b). In contrast, "artificial” (nonphysiological) $\Delta$ FosB overexpression in Drd2-expressing neurons has no effect on unconditioned aggression but reduces aggression CPP. To determine whether such a cell-type-specific dichotomy is relevant to operant aggression and aggression seeking, we performed ISH for colocalization of Fos with Drd1- and Drd2-expressing neurons following both behaviors. In contract to $\Delta$ FosB, we observed significant colocalization of Fos with both Drd1- and Drd2-expressing neurons under both experimental conditions. However, like the cell-type-specific role of $\triangle$ FosB in aggression CPP, we observed that Drd1- but not Drd2-expressing neurons are required for both operant aggression self-administration and aggression seeking.

Finally, recent studies reported roles of other cell-typespecific circuits in aggression reward, as assessed in the selfadministration and CPP procedures (Aleyasin et al., 2018a; Yamaguchi and Lin, 2018). These include estrogen-receptor $\alpha 1$ expressing neurons of ventromedial hypothalamus (Falkner et al., 2016), dopamine transporter-expressing neurons of hypothalamic ventral premammillary nucleus projecting to supramammillary nuclei (Stagkourakis et al., 2018), and GABAergic projections from basal forebrain to lateral habenula (Golden et al., 2016). The mechanistic connection between these dopamineindependent findings and our results on the selective role of NAc Drd1-expressing neurons is a subject for future research. Another question for future research is whether NAc Drd1 role in aggression reward and aggression seeking identified in our study is mediated by Drd1-expressing neurons in core, shell, or both subregions. These subregions play different roles in different forms of motivated behaviors (Kelley and Berridge, 2002; Berridge and Kringelbach, 2015), including drug reward and relapse (Bossert et al., 2013; Scofield et al., 2016).

\section{Methodological and experimental considerations}

To test causal roles of NAc-cell types in aggression selfadministration and aggression seeking, we validated a previously introduced hybrid breeding strategy that we and others used in the resident-intruder (Golden et al., 2017b) and aggression CPP (Aleyasin et al., 2018b) procedures. With this strategy, we breed transgenic inbred lines of interest (Drd1- and Drd2-Cre) with outbred CD-1 mice and use the aggressive hybrid D1-Cre and D2-Cre $\times$ CD-1 F1 generation as the subjects. In agreement with our previous findings with outbred CD-1 mice (Golden et al., 2017a), we observed individual differences with $\sim 30-50 \%$ of the F1 hybrids do not acquire operant aggression self-administration. The neurobiological mechanisms of these individual differences variation are unknown and are an important topic for future studies.

We use this breeding approach because we observed low level of aggressive behavior in the traditional C57-based transgenic mice, which show minimal aggressive behavior in the residentintruder task (Golden et al., 2017b) and fail to acquire aggression self-administration in our procedure (unpublished data). It is possible to instigate unconditioned aggressive behavior in inbred mice by exposing them to different stressors (e.g., footshock, early life isolation, or repeated instigation; Kudryavtseva et al., 2014). However, these manipulations often require weeks of repeated instigated resident-intruder pairings, which induces severe stress responses (Kudryavtseva et al., 2004), making it difficult to differentiate between appetitive and reactive aggression.

We combined the above breeding procedure using low-dose clozapine as a ligand for DREADD activation. We used a behaviorally subthreshold clozapine dose, because it was recently shown that $\mathrm{CNO}$, the "standard" DREADD ligand, is not behaviorally inert (MacLaren et al., 2016), does not cross the blood-brain-barrier (BBB), and after systemic injections, its behavioral and physiological effects are mediated via retro-converted clozapine, which crosses the $\mathrm{BBB}$, and binds at high affinity to hM4Di and hM3Dq (Gomez et al., 2017). We observed that a $0.1 \mathrm{mg} / \mathrm{kg}$ clozapine dose has no sedative effects on operant responding in well trained CD-1 mice but significantly reduced Fos expression in the NAc of hM4Di-infected, but not mCherry-infected, Drd1- and Drd2-Cre F1 hybrids. Thus, it is unlikely that under our experimental condition the observed behavioral effects are mediated by clozapine's effects on non-hM4Diinfected cells in NAc or other regions.

Finally, NAc dopamine is known to play a role in food reward (Wise, 2004), and from this perspective the observation that hM4Di inhibition of local Drd1- or Drd2-expressing neurons has no effect on food self-administration and seeking is unexpected. However, in our study we trained our mice under low effort (FR1) reinforcement schedule and under these training conditions, we and others found that NAc injections of SCH23390 have no effect on food selfadministration in rats (Bossert et al., 2007; Marchant and Kaganovsky, 2015). Our negative food data using a chemogenetic approach in mice and the previous negative data mentioned above using intracranial drug injections agree with Salamone's (2016) notion of the selective role of NAc dopamine in controlling high-effort but not low-effort food-reinforced responding.

\section{Concluding remarks and clinical implications}

Aggression is the direct cause of suffering and death for millions of people around the world (Sumner et al., 2015). Like addictive drugs, aggression can be highly rewarding, pursued despite immediate or long-term adverse consequences (Gan et al., 2016; Chester and DeWall, 2017), and sought anew after lengthy enforced abstinence (Durose et al., 2014). As such, it is not surprising that aggression is commonly comorbid with other neuropsychiatric disorders (Anderson, 2012; Beck et al., 2014). Clinically, the most common pharmacotherapeutic approach to treating aggression is the use of neuroleptic dopamine antagonists, like haloperidol (Ostinelli et al., 2017), although the efficacy of such treatments is often because of the neuroleptic's sedative effects (Calver et al., 2015). Our results suggest that for some maladaptive appetitive aggression, targeting brain Drd1-expressing neurons offers an alternative approach.

\section{References}

Aleyasin H, Flanigan ME, Russo SJ (2018a) Neurocircuitry of aggression and aggression seeking behavior: nose poking into brain circuitry controlling aggression. Curr Opin Neurobiol 49:184-191.

Aleyasin H, Flanigan ME, Golden SA, Takahashi A, Menard C, Pfau ML, Multer J, Pina J, McCabe KA, Bhatti N, Hodes GE, Heshmati M, Neve RL, Nestler EJ, Heller EA, Russo SJ (2018b) Cell-type-specific role of DeltaFosB in nucleus accumbens in modulating intermale aggression. J Neurosci 38:5913-5924. 
Anderson DJ (2012) Optogenetics, sex, and violence in the brain: implications for psychiatry. Biol Psychiatry 71:1081-1089.

Bannai M, Fish EW, Faccidomo S, Miczek KA (2007) Anti-aggressive effects of agonists at 5-HT1B receptors in the dorsal raphe nucleus of mice. Psychopharmacology (Berl) 193:295-304.

Beck A, Heinz AJ, Heinz A (2014) Translational clinical neuroscience perspectives on the cognitive and neurobiological mechanisms underlying alcohol-related aggression. Curr Top Behav Neurosci 17:443-474.

Becker EA, Marler CA (2015) Postcontest blockade of dopamine receptors inhibits development of the winner effect in the California mouse (Peromyscus californicus). Behav Neurosci 129:205-213.

Berridge KC, Kringelbach ML (2015) Pleasure systems in the brain. Neuron 86:646-664.

Berton O, McClung CA, Dileone RJ, Krishnan V, Renthal W, Russo SJ, Graham D, Tsankova NM, Bolanos CA, Rios M, Monteggia LM, Self DW, Nestler EJ (2006) Essential role of BDNF in the mesolimbic dopamine pathway in social defeat stress. Science 311:864-868.

Bossert JM, Poles GC, Wihbey KA, Koya E, Shaham Y (2007) Differential effects of blockade of dopamine D1-family receptors in nucleus accumbens core or shell on reinstatement of heroin seeking induced by contextual and discrete cues. J Neurosci 27:12655-12663.

Bossert JM, Marchant NJ, Calu DJ, Shaham Y (2013) The reinstatement model of drug relapse: recent neurobiological findings, emerging research topics, and translational research. Psychopharmacology 229:453-476.

Boyajian CL, Leslie FM (1987) Pharmacological evidence for alpha-2 adrenoceptor heterogeneity: differential binding properties of $\left[{ }^{3} \mathrm{H}\right]$ rauwolscine and $\left[{ }^{3} \mathrm{H}\right]$ idazoxan in rat brain. J Pharmacol Exp Ther 241:1092-1098.

Briggs CA, Pollock NJ, Frail DE, Paxson CL, Rakowski RF, Kang CH, Kebabian JW (1991) Activation of the 5-HT1C receptor expressed in Xenopus oocytes by the benzazepines SCH 23390 and SKF 38393. Br J Pharmacol 104:1038-1044.

Calu DJ, Chen YW, Kawa AB, Nair SG, Shaham Y (2014) The use of the reinstatement model to study relapse to palatable food seeking during dieting. Neuropharmacology 76:395-406.

Calver L, Drinkwater V, Gupta R, Page CB, Isbister GK (2015) Droperidolv. haloperidol for sedation of aggressive behaviour in acute mental health: randomised controlled trial. Br J Psychiatry 206:223-228.

Caprioli D, Zeric T, Thorndike EB, Venniro M (2015) Persistent palatable food preference in rats with a history of limited and extended access to methamphetamine self-administration. Addict Biol 20:913-926.

Caprioli D, Venniro M, Zhang M, Bossert JM, Warren BL, Hope BT, Shaham Y (2017) Role of dorsomedial striatum neuronal ensembles in incubation of methamphetamine craving after voluntary abstinence. J Neurosci 37:1014-1027.

Carle TL, Ohnishi YN, Ohnishi YH, Alibhai IN, Wilkinson MB, Kumar A, Nestler EJ (2007) Proteasome-dependent and -independent mechanisms for FosB destabilization: identification of FosB degron domains and implications for $\delta$ FosB stability. Eur J Neurosci 25:3009-3019.

Chester DS, DeWall CN (2016) The pleasure of revenge: retaliatory aggression arises from a neural imbalance toward reward. Soc Cogn Affect Neurosci 11:1173-1182.

Chester DS, DeWall CN (2017) Combating the sting of rejection with the pleasure of revenge: a new look at how emotion shapes aggression. J Pers Soc Psychol 112:413-430.

Chester DS, DeWall CN, Derefinko KJ, Estus S, Lynam DR, Peters JR, Jiang Y (2016) Looking for reward in all the wrong places: dopamine receptor gene polymorphisms indirectly affect aggression through sensationseeking. Soc Neurosci 11:487-494.

Couppis MH, Kennedy CH (2008) The rewarding effect of aggression is reduced by nucleus accumbens dopamine receptor antagonism in mice. Psychopharmacology 197:449-456.

Covington HE 3rd, Newman EL, Tran S, Walton L, Hayek W, Leonard MZ, DeBold JF, Miczek KA (2018) The urge to fight: persistent escalation by alcohol and role of NMDA receptors in mice. Front Behav Neurosci 12:206.

Cruz FC, Koya E, Guez-Barber DH, Bossert JM, Lupica CR, Shaham Y, Hope BT (2013) New technologies for examining the role of neuronal ensembles in drug addiction and fear. Nat Rev Neurosci 14:743-754.

de Almeida RM, Cabral JC, Narvaes R (2015) Behavioural, hormonal and neurobiological mechanisms of aggressive behaviour in human and nonhuman primates. Physiol Behav 143:121-135.

Dölen G, Darvishzadeh A, Huang KW, Malenka RC (2013) Social reward requires coordinated activity of nucleus accumbens oxytocin and serotonin. Nature 501:179-184.

Durose M, Cooper A, Synder H (2014) Recidivism of prisoners released in 30 states in 2005: patterns from 2005 to 2010. In: Recidivism of prisoners released series (Statistics BoJ, ed). Washington, DC: U.S. Department of Justice.

Falkner AL, Grosenick L, Davidson TJ, Deisseroth K, Lin D (2016) Hypothalamic control of male aggression-seeking behavior. Nat Neurosci 19:596-604.

Ferrari PF, van Erp AM, Tornatzky W, Miczek KA (2003) Accumbal dopamine and serotonin in anticipation of the next aggressive episode in rats. Eur J Neurosci 17:371-378.

Fish EW, De Bold JF, Miczek KA (2002) Aggressive behavior as a reinforcer in mice: activation by allopregnanolone. Psychopharmacology 163:459-466.

Fish EW, DeBold JF, Miczek KA (2005) Escalated aggression as a reward: corticosterone and GABA(A) receptor positive modulators in mice. Psychopharmacology 182:116-127.

Flanigan M, Aleyasin H, Takahashi A, Golden SA, Russo SJ (2017) An emerging role for the lateral habenula in aggressive behavior. Pharmacol Biochem Behav 162:79-86.

Fox ME, Chandra R, Menken MS, Larkin EJ, Nam H, Engeln M, Francis TC, Lobo MK (2018) Dendritic remodeling of D1 neurons by RhoA/Rhokinase mediates depression-like behavior. Mol Psychiatry. Advance online publication. Retrieved August 17, 2018. doi:10.1038/s41380-018-0211-5.

Fragoso VM, Hoppe LY, de Araújo-Jorge TC, de Azevedo MJ, Campos JD, Cortez CM, de Oliveira GM (2016) Use of haloperidol and risperidone in highly aggressive Swiss Webster mice by applying the model of spontaneous aggression (MSA). Behav Brain Res 301:110-118.

Francis TC, Chandra R, Friend DM, Finkel E, Dayrit G, Miranda J, Brooks JM, Iñiguez SD, O’Donnell P, Kravitz A, Lobo MK (2015) Nucleus accumbens medium spiny neuron subtypes mediate depression-related outcomes to social defeat stress. Biol Psychiatry 77:212-222.

Franklin KB, Paxinos G (2013) The mouse brain in stereotaxic coordinates, Ed 4. Amsterdam: Academic.

Gan G, Preston-Campbell RN, Moeller SJ, Steinberg JL, Lane SD, Maloney T, Parvaz MA, Goldstein RZ, Alia-Klein N (2016) Reward vs. retaliationthe role of the mesocorticolimbic salience network in human reactive aggression. Front Behav Neurosci 10:179.

Gerfen CR (1992) The neostriatal mosaic: multiple levels of compartmental organization. Trends Neurosci 15:133-139.

Gerfen CR, Engber TM, Mahan LC, Susel Z, Chase TN, Monsma FJ Jr, Sibley DR (1990) D1 and D2 dopamine receptor-regulated gene expression of striatonigral and striatopallidal neurons. Science 250:1429-1432.

Golden SA, Shaham Y (2018) Aggression addiction and relapse: a new frontier in psychiatry. Neuropsychopharmacology 43:224-225.

Golden SA, Covington HE 3rd, Berton O, Russo SJ (2011) A standardized protocol for repeated social defeat stress in mice. Nat Protoc 6:1183-1191.

Golden SA, Heshmati M, Flanigan M, Christoffel DJ, Guise K, Pfau ML, Aleyasin H, Menard C, Zhang H, Hodes GE, Bregman D, Khibnik L, Tai J, Rebusi N, Krawitz B, Chaudhury D, Walsh JJ, Han MH, Shapiro ML, Russo SJ (2016) Basal forebrain projections to the lateral habenula modulate aggression reward. Nature 534:688-692.

Golden SA, Heins C, Venniro M, Caprioli D, Zhang M, Epstein DH, Shaham Y (2017a) Compulsive addiction-like aggressive behavior in mice. Biol Psychiatry 82:239-248.

Golden SA, Aleyasin H, Heins R, Flanigan M, Heshmati M, Takahashi A, Russo SJ, Shaham Y (2017b) Persistent conditioned place preference to aggression experience in adult male sexually-experienced CD-1 mice. Genes Brain Behav 16:44-55.

Gomez JL, Bonaventura J, Lesniak W, Mathews WB, Sysa-Shah P, Rodriguez LA, Ellis RJ, Richie CT, Harvey BK, Dannals RF, Pomper MG, Bonci A, Michaelides M (2017) Chemogenetics revealed: DREADD occupancy and activation via converted clozapine. Science 357:503-507.

Grueter BA, Robison AJ, Neve RL, Nestler EJ, Malenka RC (2013) FosB differentially modulates nucleus accumbens direct and indirect pathway function. Proc Natl Acad Sci U S A 110:1923-1928.

Heinsbroek JA, Neuhofer DN, Griffin WC 3rd, Siegel GS, Bobadilla AC, Kupchik YM, Kalivas PW (2017) Loss of plasticity in the D2-accumbens pallidal pathway promotes cocaine seeking. J Neurosci 37:757-767.

Hunt WA, Barnett LW, Branch LG (1971) Relapse rates in addiction programs. J Clin Psychol 27:455-456.

Kelley AE, Berridge KC (2002) The neuroscience of natural rewards: relevance to addictive drugs. J Neurosci 22:3306-3311. 
Krishnan V, Han MH, Graham DL, Berton O, Renthal W, Russo SJ, Laplant Q, Graham A, Lutter M, Lagace DC, Ghose S, Reister R, Tannous P, Green TA, Neve RL, Chakravarty S, Kumar A, Eisch AJ, Self DW, Lee FS, et al. (2007) Molecular adaptations underlying susceptibility and resistance to social defeat in brain reward regions. Cell 131:391-404.

Kudryavtseva NN, Bakshtanovskaya IV, Koryakina LA (1991) Social model of depression in mice of C57BL/6J strain. Pharmacol Biochem Behav $38: 315-320$

Kudryavtseva NN, Lipina TV, Koryakina LA (1999) Effects of haloperidol on communicative and aggressive behavior in male mice with different experiences of aggression. Pharmacol Biochem Behav 63:229-236.

Kudryavtseva NN, Bondar NP, Avgustinovich DF (2004) Effects of repeated experience of aggression on the aggressive motivation and development of anxiety in male mice. Neurosci Behav Physiol 34:721-730.

Kudryavtseva NN, Smagin DA, Kovalenko IL, Vishnivetskaya GB (2014) Repeated positive fighting experience in male inbred mice. Nat Protoc 9:2705-2717.

Kupchik YM, Brown RM, Heinsbroek JA, Lobo MK, Schwartz DJ, Kalivas PW (2015) Coding the direct/indirect pathways by D1 and D2 receptors is not valid for accumbens projections. Nat Neurosci 18:1230-1232.

Lacourse E, Côté S, Nagin DS, Vitaro F, Brendgen M, Tremblay RE (2002) A longitudinal-experimental approach to testing theories of antisocial behavior development. Dev Psychopathol 14:909-924.

Lawler CP, Prioleau C, Lewis MM, Mak C, Jiang D, Schetz JA, Gonzalez AM, Sibley DR, Mailman RB (1999) Interactions of the novel antipsychotic aripiprazole (OPC-14597) with dopamine and serotonin receptor subtypes. Neuropsychopharmacology 20:612-627.

Li X, Rubio FJ, Zeric T, Bossert JM, Kambhampati S, Cates HM, Kennedy PJ, Liu QR, Cimbro R, Hope BT, Nestler EJ, Shaham Y (2015) Incubation of methamphetamine craving is associated with selective increases in expression of $B d n f$ and $\operatorname{TrkB}$, glutamate receptors, and epigenetic enzymes in cue-activated Fos-expressing dorsal striatal neurons. J Neurosci 35:8232-8244.

Lobo MK, Covington HE 3rd, Chaudhury D, Friedman AK, Sun H, DamezWerno D, Dietz DM, Zaman S, Koo JW, Kennedy PJ, Mouzon E, Mogri M, Neve RL, Deisseroth K, Han MH, Nestler EJ (2010) Cell type-specific loss of BDNF signaling mimics optogenetic control of cocaine reward. Science 330:385-390.

MacLaren DA, Browne RW, Shaw JK, Krishnan Radhakrishnan S, Khare P, España RA, Clark SD (2016) Clozapine $\mathrm{N}$-oxide administration produces behavioral effects in Long-Evans rats: implications for designing DREADD experiments. eNeuro 3:ENEURO.0219-16.2016.

Marchant NJ, Kaganovsky K (2015) A critical role of nucleus accumbens dopamine D1-family receptors in renewal of alcohol seeking after punishment-imposed abstinence. Behav Neurosci 129:281-291.

May ME, Kennedy CH (2009) Aggression as positive reinforcement in mice under various ratio- and time-based reinforcement schedules. J Exp Anal Behav 91:185-196.

Miczek KA (1974) Intraspecies aggression in rats: effects of D-amphetamine and chlordiazepoxide. Psychopharmacologia 39:275-301.

Miczek KA, Haney M (1994) Psychomotor stimulant effects of D-amphetamine, MDMA and PCP: aggressive and schedule-controlled behavior in mice. Psychopharmacology 115:358-365.

Millan MJ, Brocco M, Gobert A, Dorey G, Casara P, Dekeyne A (2001) Anxiolytic properties of the selective, non-peptidergic CRF(1) antagonists, CP154,526 and DMP695: a comparison to other classes of anxiolytic agent. Neuropsychopharmacology 25:585-600.

Moran JK, Weierstall R, Elbert T (2014) Differences in brain circuitry for appetitive and reactive aggression as revealed by realistic auditory scripts. Front Behav Neurosci 8:425.

Morgan JI, Curran T (1991) Stimulus-transcription coupling in the nervous system: involvement of the inducible proto-oncogenes Fos and Jun. Annu Rev Neurosci 14:421-451.

Nautiyal KM, Tanaka KF, Barr MM, Tritschler L, Le Dantec Y, David DJ, Gardier AM, Blanco C, Hen R, Ahmari SE (2015) Distinct circuits underlie the effects of 5-HT1B receptors on aggression and impulsivity. Neuron 86:813-826.

Nehrenberg DL, Sheikh A, Ghashghaei HT (2013) Identification of neuronal loci involved with displays of affective aggression in NC900 mice. Brain Struct Funct 218:1033-1049.

Nestler EJ (2015) FosB: a transcriptional regulator of stress and antidepressant responses. Eur J Pharmacol 753:66-72.
Neumeyer JL, Kula NS, Bergman J, Baldessarini RJ (2003) Receptor affinities of dopamine D1 receptor-selective novel phenylbenzazepines. Eur J Pharmacol 474:137-140.

Ostinelli EG, Brooke-Powney MJ, Li X, Adams CE (2017) Haloperidol for psychosis-induced aggression or agitation (rapid tranquillisation). Cochrane Database Syst Rev 7:CD009377.

Pickens CL, Cifani C, Navarre BM, Eichenbaum H, Theberge FR, Baumann MH, Calu DJ, Shaham Y (2012) Effect of fenfluramine on reinstatement of food seeking in female and male rats: implications for the predictive validity of the reinstatement model. Psychopharmacology 221:341-353.

Porges EC, Decety J (2013) Violence as a source of pleasure or displeasure is associated with specific functional connectivity with the nucleus accumbens. Front Hum Neurosci 7:447.

Porter RH, Benwell KR, Lamb H, Malcolm CS, Allen NH, Revell DF, Adams DR, Sheardown MJ (1999) Functional characterization of agonists at recombinant human 5-HT2A, 5-HT2B and 5-HT2C receptors in CHO-K1 cells. Br J Pharmacol 128:13-20.

Provençal N, Booij L, Tremblay RE (2015) The developmental origins of chronic physical aggression: biological pathways triggered by early life adversity. J Exp Biol 218:123-133.

Robison AJ, Nestler EJ (2011) Transcriptional and epigenetic mechanisms of addiction. Nat Rev Neurosci 12:623-637.

Rubio FJ, Liu QR, Li X, Cruz FC, Leão RM, Warren BL, Kambhampati S, Babin KR, McPherson KB, Cimbro R, Bossert JM, Shaham Y, Hope BT (2015) Context-induced reinstatement of methamphetamine seeking is associated with unique molecular alterations in Fos-expressing dorsolateral striatum neurons. J Neurosci 35:5625-5639.

Salamone JD, Correa M, Yohn S, Lopez Cruz L, San Miguel N, Alatorre L (2016) The pharmacology of effort-related choice behavior: dopamine, depression, and individual differences. Behav Processes 127:3-17.

Scofield MD, Heinsbroek JA, Gipson CD, Kupchik YM, Spencer S, Smith AC, Roberts-Wolfe D, Kalivas PW (2016) The nucleus accumbens: mechanisms of addiction across drug classes reflect the importance of glutamate homeostasis. Pharmacol Rev 68:816-871.

Sinha R (2011) New findings on biological factors predicting addiction relapse vulnerability. Curr Psychiatry Rep 13:398-405.

Stagkourakis S, Spigolon G, Williams P, Protzmann J, Fisone G, Broberger C (2018) A neural network for intermale aggression to establish social hierarchy. Nat Neurosci 21:834-842.

Sumner SA, Mercy JA, Dahlberg LL, Hillis SD, Klevens J, Houry D (2015) Violence in the united states: status, challenges, and opportunities. JAMA 314:478-488.

Tang L, Todd RD, Heller A, O'Malley KL (1994) Pharmacological and functional characterization of D2, D3 and D4 dopamine receptors in fibroblast and dopaminergic cell lines. J Pharmacol Exp Ther 268:495-502.

van Erp AM, Miczek KA (2000) Aggressive behavior, increased accumbal dopamine, and decreased cortical serotonin in rats. J Neurosci 20:9320-9325.

van Erp AM, Miczek KA (2007) Increased accumbal dopamine during daily alcohol consumption and subsequent aggressive behavior in rats. Psychopharmacology 191:679-688.

Venniro M, Caprioli D, Zhang M, Whitaker LR, Zhang S, Warren BL, Cifani C, Marchant NJ, Yizhar O, Bossert JM, Chiamulera C, Morales M, Shaham Y (2017) The anterior insular cortex $\rightarrow$ central amygdala glutamatergic pathway is critical to relapse after contingency management. Neuron 96:414-427.e8.

Venniro M, Zhang M, Caprioli D, Golden SA, Heins C, Hoots JK, Epstein DH, Morales M, Shaham Y (2018) Volitional social interaction prevents drug addiction in rat models. Nat Neurosci 21:1520-1529.

Walsh JJ, Christoffel DJ, Heifets BD, Ben-Dor GA, Selimbeyoglu A, Hung LW, Deisseroth K, Malenka RC (2018) 5-HT release in nucleus accumbens rescues social deficits in mouse autism model. Nature 560:589-594.

Wise RA (2004) Dopamine, learning and motivation. Nat Rev Neurosci 5:483-494.

Yamaguchi T, Lin D (2018) Functions of medial hypothalamic and mesolimbic dopamine circuitries in aggression. Curr Opin Behav Sci 24:104-112.

Yu Q, Teixeira CM, Mahadevia D, Huang Y, Balsam D, Mann JJ, Gingrich JA, Ansorge MS (2014) Dopamine and serotonin signaling during two sensitive developmental periods differentially impact adult aggressive and affective behaviors in mice. Mol Psychiatry 19:688-698. 